\title{
DIPLOMACY UNDER OCCUPATION. THE STATUS OF DIPLOMATIC MISSIONS IN OCCUPIED IRAQ
}

\author{
Stefan TALMON*
}

RESUMEN: La ocupación no termina automáticamente relaciones diplomáticas o cierra misiones diplomáticas, pero el poder ocupante puede pedir de otros países que saquen temporalmente a miembros de misiones diplomáticas o la misión misma. La Convención de Viena de Relaciones Diplomáticas no se aplica directamente a poderes ocupantes con respecto a misiones diplomáticas y sus miembros en el territorio ocupado. El territorio es gobernado bajo las reglas usuales de la guerra. Aunque los agentes diplomáticos mantienen su estatus como diplomáticos, estos agentes no disfrutan de todas sus inmunidades y privilegios diplomáticos. Estos privilegios serán en práctica limitados por las necesidades militares y de seguridad del poder ocupante. El poder ocupante puede permitir a diplomáticos en el territorio, pero no puede acreditar a otros agentes, los cuales serán reconocidos al regreso del gobierno legítimo del estado.

ABSTRACT: Occupation does not automatically terminate diplomatic relations or end diplomatic missions but the occupant may request the sending State temporarily to recall individual members of a diplomatic mission or the mission itself. The Vienna Convention on Diplomatic Relations is not directly applicable to the occupying power with respect to diplomatic missions and their members in occupied territory; the question continues to be governed by the customary law of war rules. While diplomatic agents in occupied territory retain their diplomatic status, they cannot expect to enjoy all their immunities and privileges to the fullest extent. These will in practice be limited by the military necessities and security concerns of the belligerent occupant. The occupant may admit foreign diplomats to the occupied territory, but cannot take accreditations for diplomatic agents binding on the (returning) legitimate government of the occupied State.

RÉSUMÉ: L'occupation ne termine pas automatiquement les relations diplomatiques ou les missions diplomatiques, mais l'occupant peut demander à l'État accréditant de rappeler temporairement les membres individuels d'une mission diplomatique, ou la mission elle-même. La Convention de Vienne sur les Relations Diplomatiques n'est pas directement applicable à la puissance occupante à l'égard des missions diplomatiques et de leurs membres en territoire occupé; la question est gouvernée par le droit coutumier de la guerre. Les agents diplomatiques dans le territoire occupé continuent de jouir du statut diplomatique, mais ils ne peuvent s'attendre à jouir de l'ensemble des immunités et privilèges diplomatiques. Dans la pratique, ils seront limités par les besoins militaires et les conditions de sécurité de l'occupant belligérant. L'occupant peut accepter des diplomates étrangers dans le territoire occupé, mais il ne peut accepter d'accréditations d'agents diplomatiques sans compromettre les droits du gouvernement légitime de l'État occupé.

* University Lecturer in Public International Law, University of Oxford, and Fellow of St. Anne's College, Oxford.

Anuario Mexicano de Derecho Internacional, vol. VI, 2006, pp. 461-511 
SUMARIO: I. Introduction. The US Raid on the Palestinian Embassy in Baghdad. II. Occupation and Diplomatic Relations of the Occupied State. III. The Continued Diplomatic Status of Existing Missions and Their Members. IV. Withdrawal of Diplomatic Missions and their Members from Occupied Territory. V. Application of the Vienna Convention on Diplomatic Relations to Diplomatic Missions in Occupied Territory? VI. The Treatment of Diplomatic Missions and Their Members in Occupied Territory. VII. The Establishment of Foreign Liaison Missions in Occupied Territory. VIII. Conclusions.

\section{INTRODUCTION. THE US RAID ON THE PALESTINIAN EMBASSY IN BAGHDAD}

The relevant facts of the Iraq war can be quickly recounted for the purposes of this article: on 20 March 2003, the United States and the United Kingdom invaded Iraq; on 9 April, US forces advanced into central Baghdad, the Iraqi Government collapsed and its members were apprehended or went into hiding; on 1 May, US President Bush declared an end to major combat operations in Iraq; on 16 May, the Coalition Provisional Authority (CPA) with US Ambassador Paul Brenner as administrator was established, vested with all the executive, legislative and judicial authority necessary to exercise powers of government temporarily, in order to provide for the effective administration of Iraq during the period of transitional administration; ${ }^{1}$ on 22 May, the UN Security Council adopted resolution 1483 (2003), acknowledging the United States and the United Kingdom as "occupying powers under unified command"; ${ }^{2}$ on 13 July, Iraq's Interim Governing Council, composed of 25 Iraqis appointed by the occupying powers, was inaugurated, although the CPA remained the ultimate authority; on 13 December, Saddam Hussein was captured by US troops; on 1 June 2004, the Iraqi Interim Government was established, and on 28 June the occupying powers transferred full governing authority to it.

1 See Coalition Provisional Authority Regulation Number 1, CAP/REG/16 May 2003/01,

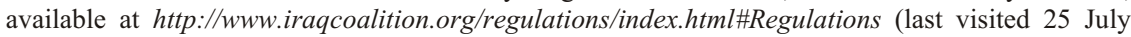
2005).

2 S/RES/1483 (2003) of 22 May 2003, preambular para. 13. 
There is no dispute that between April 2003 and 28 June 2004 Iraq was under military occupation, and during that time supreme authority in the country was exercised by the CPA. ${ }^{3}$ The occupation of Iraq has revived interest in the law of belligerent occupation and has created a vast body of literature on the subject. One incident during the occupation, however, seems to have gone largely unnoticed: the raid by US occupation forces on the Palestinian Embassy in Baghdad. ${ }^{4}$

On 28 May 2003, US troops raided the Embassy of Palestine in Baghdad and arrested, inter alia, two Palestinian diplomats - the chargé d'affaires and the commercial counsellor- and a consular officer. ${ }^{5} \mathrm{Lt}$. Gen. David D. McKiernan, commander of allied forces in Iraq, said during a news conference the following day that American soldiers had entered the Palestinian compound and conducted a search that yielded "four AK-47s, seven grenades, one MP-5, four M-9s, a 48-caliber pistol and a book on terrorism". ${ }^{6}$ The Palestinian chargé d'affaires and the commercial counsellor were detained for exactly one year at the now infamous Abu Ghraib prison in Baghdad without any charges being brought against them. ${ }^{7}$ After being closed for 80 days, the Palestinian Embassy in Baghdad reopened on 14 August 2003. ${ }^{8}$

Questioned about the raid on the Palestinian Embassy, Richard Boucher, the spokesman for the US State Department, said during the daily press briefing on 29 May 2003:

3 See Adam Roberts, "The End of Occupation: Iraq 2004", 54 International and Comparative Law Quarterly (2005), pp. 27-48 at p. 30. See also Kaiyan Homi Kaikobad, "Problems of Belligerent Occupation: The Scope of Powers Exercised by the Coalition Provisional Authority in Iraq", April/May 2003-June 2004; ibidem, pp. 253-264; Gregory H. Fox, "The Occupation of Iraq", Georgetown Journal of International Law 36 (2005), 195-297.

4 For an exception, see Frederic L. Kirgis, "Diplomatic Immunities in Iraq", ASIL Insight, June 2003.

5 The persons arrested were chargé d'affaires Najjah Abdel Rahman, consul Ibrahim Mohsen and commercial counsellor Munir Sobhi.

6 "Status of envoys in Iraq revoked; New diplomats told to stay away", Washington Post, 30 May 2003, A1; "After the War: Baghdad; U.S. Civilians Not Told of Raid on Palestinians", New York Times, 31 May 2003, A6.

7 "US forces release two senior Palestinian diplomats detained in Baghdad", BBC Worldwide Monitoring, 29 May 2004, available at http://web.lexis-nexis.com/executive/ (last visited 25 July 2005).

8 "Palestinian Embassy in Baghdad reopens after closure of 80 days", World News Connection, 19 August 2003, available at http://web.lexis-nexis.com/executive/ (last visited 25 July 2005). 
[W]e discourage foreign diplomats from entering Iraq. There is no Iraqi government for them to interact with. There is no Iraqi government to grant the privileges and immunities that diplomats would normally have inside a country... There are diplomats who were previously accredited to the Saddam regime, who have been residing in former mission residences, who are still there. We do not regard those as diplomatic missions. They=re accredited to a regime that is no longer existent, and, therefore, their accreditation would have lapsed... They and their premises don't have diplomatic status anymore. ${ }^{9}$

This incident raises the question of the status of foreign diplomatic missions and their personnel in occupied territory. There is no mention of the matter either in the Hague Regulations Respecting the Laws and Customs of War on Land (HR) ${ }^{10}$ or in the Fourth Geneva Convention Relative to the Protection of Civilian Persons in Time of War (GC IV). ${ }^{11}$ The Vienna Convention on Diplomatic Relations (VCDR) is also silent on the issue. ${ }^{12}$ In its preamble, the VCDR states, however, that "the rules of customary international law should continue to govern questions not expressly regulated by the provisions of the present Convention". ${ }^{13}$ The literature on the topic is sparse, ${ }^{14}$ and Hersch Lauterpacht stated that "the position of foreign envoys found by a belligerent on occupied enemy territory is not settled as regards details". ${ }^{15}$ It was also said that "very few legal principles exist that have specific wartime application to treatment of diplomats. Customary international law on the treatment of diplomats in wartime essentially is confined to ensuring that diplomats from neutral

9 UN Department of State, Daily Press Briefing (Corrected), Richard Boucher, Spokesman,

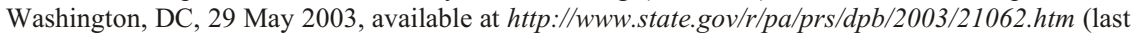
visited, 22 June 2005).

10 Regulations Respecting the Laws and Customs of War on Land, annexed to the Fourth Hague Convention Respecting the Laws and Customs of War on Land, 18 October 1907, American Journal of International Law Supplement 2 (1908), 90-117.

11 Geneva Convention Relative to the Protection of Civilian Persons in Time of War, $12 \mathrm{Au}-$ gust 1949, 75 UNTS 287.

12 Vienna Convention on Diplomatic Relations, 8 April 1961, 500 UNTS 95.

13 VCDR, preambular para. 5.

14 See e.g. Gerhard von Glahn, The Occupation of Enemy Territory . . . A Commentary on the Law and Practice of Belligerent Occupation, Minneapolis 1957, 87-90; Manfred R. Hagedorn, Die ausärtige Gewalt des Okkupanten für ein kriegerisch besetztes Gebiet, Bonn 1958; Christoph H. Seibt, "Das Recht der diplomatischen Beziehungen während kriegerischer Besetzungen", Archiv des Völkerrechts 28 (1990), 443-457.

15 Lasa Oppenheim, International Law. A Treatise, vol. II (7th edn., ed. by Hersch Lauterpacht), London 1952, 677 n. 1. 
and belligerent states are assured safe-passage, or 'safe-conduct,' to their sending states". ${ }^{16}$

This paper will examine on the basis of relevant State practice what effect belligerent occupation has on diplomatic relations of the occupied State, what rights the occupying power has with regard to foreign diplomatic missions, what status existing foreign diplomatic missions and their personnel enjoy in occupied territory, and whether new diplomatic missions may be established during occupation. The status of diplomatic missions and agents is to be distinguished from that of consular missions and officers. While the occupant has usually "withdrawn", "cancelled", "suspended" or "nullified" the exequaturs of consuls, they have nevertheless been allowed to continue to function in occupied territory, subject to certain restrictions. ${ }^{17}$

\section{OCCUPATION AND DIPLOMATIC RELATIONS OF THE OCCUPIED STATE}

Article 2 VCDR provides that diplomatic relations are established between States. The occupation of a State's territory is a factual situation of a transitory character that does not affect its existence as a State. As annexation of occupied territory is no longer lawful under current international law, the same is true for any purported "annexation" of the occupied territory. Occupation and annexation thus do not automatically terminate the occupied State's diplomatic relations with third States. In response to a statement by the US Ambassador to Russia that the United States did not view the Russian Embassy in Iraq as a diplomatic mission

16 John Embry Parkerson Jr., "United States Compliance with Humanitarian Law Respecting Civilians During Operation Just Cause", Military Law Review 131 (1991), 31-140 at 105.

17 See Papers Relating to the Foreign Relations of the United States [FRUS], 1915, Supplement, 916-921 (US consular offices in Belgium), 921-923 (US consular office in Serbia); ibidem, 1916, Supplement, 796 (US consular offices in Poland); Foreign Relations of the United States. Diplomatic Papers [FRUS], 1941, vol. II, 630 (US consular establishments in occupied Norway, Holland, Belgium, Luxembourg, France, Serbia, and Greece were closed by the German occupation authorities only on 15 July 1941 after the US Government had closed German consulates in the United States); ibidem, 67 (US consulate in Copenhagen was closed on 9 July 1941 in response to the expulsion of Danish consuls from the United States). See also United States Judge Advocate General's School, Law of Belligerent Occupation, Ann Arbor, 1944, 77-78; Stefan Talmon, Recognition of Governments in International Law, Oxford 1998, 159-160. 
and had no responsibility for its staff's security, the Russian Foreign Ministry on 12 July 2003 issued a statement which said in part:

This position is far from flawless in light of international legal norms and the generally acknowledged diplomatic practice. The 1961 Vienna Convention clearly stipulates that diplomatic relations are established between countries. Since the current occupation of Iraq does not influence the existence of Iraq as a country, its diplomatic relations with Russia are continued. The diplomats accredited in Iraq, no matter whether they are currently in Iraq or beyond it, have not lost their diplomatic status in the country. ${ }^{18}$

That diplomatic relations between Iraq and third States were unaffected by the occupation can also be seen by the fact that Iraqi diplomatic missions abroad continued to function. While on 15 May 2003 the heads of missions and other senior diplomats (ambassadors and chargés d'affaires) were ordered to return to Baghdad by 6 June 2003, Iraqi embassy staff were asked to "remain in their respective posts, safeguard equipment and facilities of the chancery and wait for further instruction". ${ }^{19}$ The Philippines Foreign Secretary said on 15 April 2003 that the Philippines "have not ceased to recognize the diplomatic character of the Iraqi embassy or its officials. They continue to enjoy the privileges and immunities accorded to them under the Vienna Convention on Diplomatic Relations, until we receive contrary information from their new government". ${ }^{20}$ On 29 July 2003, the Russian Foreign Ministry commented on the status of the Iraqi Embassy in Moscow, stating that "the 1961 Vienna Convention on Diplomatic Relation... clearly states that

18 "Moscow concerned by U.S. refusal to ensure safety of diplomats in Iraq", News Bulletin, 12 July 2003, available at http://web.lexis-nexis.com/executive/ (last visited 25 July 2005). See also the "Moscow concerned about US unwillingness to recognize diplomatic status of Russian Embassy in Baghdad", available at http://www.india.mid.ru/nfr2003/nf1807.html (last visited 25 July 2005).

19 "Iraqi envoy in Cairo reportedly severs ties with Iraqi diplomatic mission", BBC Monitoring International Reports, 10 June 2003; "Iraqi envoy to leave Philippines within a week: officials", Agence France Presse-English, 21 May 2003; "Iraqi diplomats told to report to Baghdad before June 6", Agence France Presse-English, 20 May 2003. Only six percent of Iraq's 550 diplomats were dismissed after the war. Nine out of the 44 top diplomats failed to respond to the order to return. See "Nine out of Saddam's top 44 diplomats fail to return to Baghdad", Agence France Presse-English, 12 June 2003; all available at http://web.lexis-nexis.com/executive/ (last visited 25 July 2005).

20 "Philippines prepares to send peacekeeping mission to Iraq", BBC Monitoring International Reports, 15 April 2003, available at http://web.lexis-nexis.com/executive/ (last visited 25 July 2005). 
diplomatic relations are established between states... the current invasion of Iraq does not affect its status of a State, formally, its relations with Russia have never been disrupted... its diplomats and embassy premises lose neither privileges, nor immunities." The Russian Foreign Ministry added, however, that from a practical perspective "the normal full-scale functioning of the embassy will only be restored after the formation of a legal and internationally recognized government of Iraq". ${ }^{21}$ A Historic Review of the CPA Accomplishments published on 28 June 2004 recorded that "Iraq now has diplomatic representation in 35 countries around the world, including 3 Permanent Missions to the United Nations in New York, the United Nations Commission on Human Rights in Geneva and the Arab League in Cairo. Thirty missions remain suspended". ${ }^{22}$ The diplomatic relations of Iraq thus continued, despite the fact that the State's territory was occupied.

This finding is in line with previous State practice. The various States occupied by Italy, Japan and Germany in the 1930s and 1940s continued to maintain diplomatic relations with other States, irrespective of whether their head of State or government remained in the occupied territory (Thailand, Denmark), ${ }^{23}$ fled into exile (Ethiopia, Poland, Belgium, Luxembourg, Netherlands, Norway) ${ }^{24}$ or was deposed and dissolved (Albania, Czechoslovakia, Baltic States). ${ }^{25}$ Similarly, diplomatic relations with Kuwait continued throughout the Iraqi occupation of that country during August 1990 and February 1991.26

There is also no basis in international law for the occupant having a general right to terminate diplomatic relations between the occupied and

21 "Russian Foreign Ministry: Decision on Iraqi Embassy to Moscow must be made by Iraqi side", RIA Novosti, 29 July 2003, available at http://web.lexis-nexis.com/executive/ (last visited 25 July 2005).

22 Coalition Provisional Authority, An Historic Review of CPA Accomplishments, Baghdad, Iraq, 28 June 2004, at 49, available at http://www.cpa-iraq.org/pressreleases/20040628_historic_review_cpa.doc (last visited 22 June 2005).

23 Documents on German Foreign Policy 1919-1945 [DGFP], series D, vol. IX, no. 121, 173-174 (Danish missions abroad); FRUS, 1943, vol. III, 1118 and ibidem, 1944, vol. V, 1314 (Thai Minister in Washington).

24 Talmon, supra n. 17, 159-161; Alexander Koberg, Die Exilregierung im Völkerrecht, Frankfurt am Main 2005, 146-154. See also Documents Diplomatiques Suisses 1848-1945 [DDS], vol. 13, 1060-1062; vol. 14, 1343-1344 (legations of occupied countries in Switzerland).

25 House of Commons, Debates [HC Debates], vol. 348, cols. 9-10: 5 June 1939 (Albania); ibid., 347, col. 2688: 26 May 1939; FRUS, 1941, vol. I, 710 and vol. II, 21-22, 32; DDS, vol. 13, 1062 (Czechoslovakia); DGFP, series D, vol. X, no. 328, 466; DDS, vol. 13, 1061 (Baltic States).

26 See Talmon, supra n. 17, 161-163. 
third States. According to the Operational Law Handbook issued by the United States Army Judge Advocate General's Legal Center and School, "[a] State's political independence is a direct attribute of sovereignty and includes the right to... maintain diplomatic relations with the world community". ${ }^{27}$ The termination of diplomatic relations is thus a sovereign act of the State under occupation. During the occupation, the sovereignty of the occupied State does not pass to the occupying power - the occupant exercises de facto authority rather than sovereignty-. ${ }^{28}$ It was for this reason that States in August 1990 rightly rejected the Iraqi demand to terminate diplomatic relations with Kuwait. ${ }^{29}$ For the question of sovereignty it does not make any difference whether the occupation is the result of an aggression or a precondition for the transformation of a society from a despotic and criminal regime into a democratic community. ${ }^{30}$

The situation with regard to diplomatic relations may be different if the occupation is a consequence of a comprehensive military defeat accompanied by the dissolution of the entire structure of the State. Also referred to as post-surrender occupation, this kind of occupation is more extensive and absolute and gives many more powers to the occupant. It arises in situations of ultima victoria debellatio. The best example of this situation is the post-war administration of Germany. In this case, only nominal sovereignty continues to reside in the vanquished State. ${ }^{31}$ With regard to Germany's diplomatic relations, the four Allied Powers stated in Control Council Proclamation No. 2:

7. (a) In virtue of the unconditional surrender of Germany, and as of the date of such surrender, the diplomatic, consular, commercial and other relations of the German State with other States have ceased to exist...

(c) all German diplomatic, consular, commercial and other officials and members of German service missions abroad are hereby recalled. The control and disposal of the buildings, property and archives of all German

27 Joseph B. Berger III, Derek Grimes, Eric T. Jensen (eds.), Operational Law Handbook, The Judge Advocate General's Legal Center and School, Charlottesville Va. 2004, 5.

28 See HR, Art. 43. See also UK Ministry of Defence, The Manual of the Law of Armed Conflict, Oxford 2004, 278 MN 11.9.

29 See e.g. the declaration issued at a meeting of Nordic Foreign Ministers on 11-12 September 1990: UN Doc. S/21751, 13 September 1990, 3.

30 Fox, supra n. 3, 200 rightly points out that "to permit the occupier all of the prerogatives of the ousted de jure sovereign would effectively collapse the distinction between occupation and annexation."

31 Kaikobad, supra n. 3, 260. 
diplomatic and other agencies abroad will be proscribed by the Allied Representatives. ${ }^{32}$

The situations of Iraq and Germany are quite different both in fact and law. ${ }^{33}$ No such proclamation was made by the CPA with regard to the Iraqi State's diplomatic relations, nor indeed could it be made. In resolution 1483 (2003), the UN Security Council called upon all concerned, including the occupying powers, "to comply fully with their obligations under international law including in particular the Geneva Conventions of 1949 and the Hague Regulations of 1907".34 The United Kingdom also confirmed that the Hague and Geneva regimes were applicable to the occupation of Iraq.$^{35}$ In addition, in resolution 1511 (2003) the Council underscored that "the sovereignty of Iraq resides in the State of Iraq" and reaffirmed "the temporary nature of the exercise by the Coalition Provisional Authority (Authority) of the specific responsibilities, authorities, and obligations under applicable international law". ${ }^{36}$

While the occupying power cannot terminate the occupied State's diplomatic relations with third States, the third States themselves are free to do so. In response to the US raid on the Palestinian Embassy in Baghdad and the announcement that foreign missions in Iraq no longer enjoyed diplomatic status, Libya on 1 June announced its intention "to cut diplomatic relations with Iraq, to close its embassy in Baghdad and recall all its personnel". ${ }^{37}$ In different circumstances, the Swiss Federal Council decided on 8 May 1945 not to recognize any German Government and, consequently, to close the Swiss Legation in Germany and to recall its minister. The German missions (both diplomatic and consular) in Switzerland were to be closed and the premises and archives were to be taken

32 Enactments and Approved Papers of the Control Council and Coordinating Committee, Berlin 1945, vol. I, 83.

33 See Kaikobad, supra n. 3, 261-262; Fox, supra n. 3, 289-294, 296.

34 S/RES/1483 (2003) of 22 May 2003, para. 5.

35 UK Foreign Affairs Committee, Tenth Report, Foreign Policy Aspects of the War Against Terrorism, Written Evidence, Memorandum from the Foreign and Commonwealth Office, 18 June 2003, para. 4, available at $h t t p: / / w w w . p u b l i c a t i o n s . p a r l i a m e n t . u k / p a / c m 200203 / \mathrm{cmselect} / \mathrm{cmfaff} / 405 /$ 405we04.htm (last visited 25 July 2005).

36 S/RES/1511 (2003) of 16 October 2003, preambular para. 2 and para. 1.

37 "Libya breaks diplomatic ties with Iraq, closes Baghdad embassy", Agence France Presse English, 1 June 2003, available at http://web.lexis-nexis.com/executive/ (last visited 25 July 2005). 
into safekeeping for a future successor of the present unrecognized German Government. ${ }^{38}$

\section{The ContinUed Diplomatic Status of EXISTING MISSIONS AND THEIR MEMBERS}

According to the spokesman for the US State Department, the "diplomats who were previously accredited to the Saddam regime... and their premises don't have diplomatic status anymore". ${ }^{39}$ He explained this by pointing to the fact the diplomats were accredited to a regime that no longer existed, and, therefore, their accreditation had lapsed. This position is reminiscent of Art. 9 of the Instructions for the Government of Armies of the United States in the Field of 1863 (the so-called "Lieber Code") which stated that: "the functions of ambassadors, ministers, and other diplomatic agents accredited by neutral powers to the hostile government, cease, so far as regards the displaced government; but the conquering or occupying power usually recognizes them as temporarily accredited to itself". ${ }^{40}$

When the Central Powers in December 1916 requested neutral governments to withdraw their diplomatic missions from occupied Bucharest, the German Secretary of State for Foreign Affairs justified the request in a similar vein by arguing that "international law does not recognize the status of a diplomat accredited to the government of a country which is under military occupation of another power". ${ }^{41}$ It seems that the United States adopted a similar position with regard to neutral diplomatic missions in occupied Japan. A Memorandum of the General Headquarters, Allied Powers, Japan, dated 18 November 1945, reads: "As regards the maintenance of neutral liaison officers in Japan, the Supreme Commander is taking steps to inform the neutral governments concerned that they may appoint diplomatic agents or representatives of

38 DDS, vol. 15, no. 441, 1106-1107.

39 UN Department of State, Daily Press Briefing (Corrected), Richard Boucher, Spokesman, Washington, DC, 29 May 2003, available at http://www.state.gov/r/pa/prs/dpb/2003/21062.htm (last visited, 22 June 2005).

40 Instructions for the Government of Armies of the United States in the Field, General Orders, No. 1000, 24 April 1863, Art. 9; quoted in John Bassett Moore, A Digest of International Law, Washington 1906, vol. VII, ' 1147 at 277.

41 James Wilford Garner, International Law and the World War, London 1922, vol. I, 52; Cecil Hurst, "Les immunités diplomatiques", Recueil des Cours 12 (1926-II), 119-241 at 232-233. 
that character to maintain contact with the Supreme Commander for the Allied Powers". ${ }^{42}$

The argument of the United States with regard to foreign diplomatic missions in Iraq has several flaws. ${ }^{43}$ First of all, it is useful to distinguish between individual "members of the mission" and "permanent diplomatic missions". ${ }^{4}$ A permanent diplomatic mission usually continues, even though the function of the head of mission or other members of the staff of the mission has come to an end. Permanent diplomatic missions are "established" by mutual consent of the sending and the receiving State. They are not "accredited" to a particular government or regime. ${ }^{45}$ Diplomatic missions, like treaties, are creating rights and obligations for States, independent of their respective governments. A permanent diplomatic mission comes to an end only if diplomatic relations are broken off between the sending and receiving States, or if a mission is permanently or temporarily recalled. ${ }^{46}$ As shown above, the occupying power cannot end diplomatic relations between the occupied and third States. Diplomatic missions can thus only come to an end with the (temporary) recall of the mission by the sending State. This seems to have been acknowledged, at least implicitly, by the Security Council which, in resolution 1511 (2003) unequivocally condemned "the terrorist bombings of the Embassy of Jordan on 7 August 2003... and of the Embassy of Turkey on 14 October 2003, the murder of a Spanish diplomat on 9 October 2003". ${ }^{47}$

State practice shows that changes of the head of State (either constitutional or revolutionary), or changes of its government, the fact that the head of State (and/or its government) are forced into exile, the dissolu-

42 See Fukuo Yamaguchi, "Suspension of Diplomatic Relations between Occupied Japan and Neutral States", Zeitschrift für ausländisches öffentliches Recht und Völkerrecht 42 (1982), 100-120 at 107-108. It is of interest to note that the decision of the Supreme Commander, Allied Powers, Japan (McArthur) to suspend diplomatic relations between the Japanese Government and third States "did not relieve the Japanese Government of its responsibility to provide suitable quarters, fuel, subsistence, medical and other care to foreign diplomats [in occupied Japan] on the standard scale and in accord with international custom" (FRUS, 1945, vol. VI, 882 and ibidem, 852).

43 Von Glahn in 1957 referred to it as the view taken by older writers; see, supra n. 14, 87, with further references.

44 Cf. VCDR, Art. 1(b) and Art. 2. See also Robert Jennings and Arthur Watts (eds.), Oppenheim's International Law, 9th edn., Harlow 1992, 1117, ' 519.

45 See VCDR, Art. 2.

46 VCDR, Art. 45.

47 S/RES/1511 (2003) of 16 October 2003, para. 18. 
tion of a State's government, ${ }^{48}$ or the occupation of a State's territory do not automatically terminate a diplomatic mission ipso facto, or affect the diplomatic status of the mission. ${ }^{49}$ The 1928 Inter-American Convention on Diplomatic Officers expressly states that neither the death or resignation of the Head of State, nor the change of government or political regime in the receiving State terminate the mission of diplomatic officers. ${ }^{50}$ The following examples seem particularly pertinent to the present case:(i) Germany occupied Belgium in August 1914 and the Belgian Government went into exile. Nevertheless, the United States Minister at Brussels continued to function in Belgium and enjoyed diplomatic privileges and immunities until the break in relations between the United States and Germany on 3 February $1917 .{ }^{51}$ Similarly, the Spanish Minister remained in Brussels throughout the occupation. ${ }^{52}$ (ii) On 3 October 1935, Italy invaded Ethiopia (Abyssinia), and on 2 May 1936 Italian forces under Marshal Badoglio occupied Addis Ababa. The Emperor fled into exile and the Ethiopian Government dispersed and went into hiding. Nevertheless, Great Britain and several other countries continued to maintain their legations in Addis Ababa until 21 December 1936,,$^{53}$ despite "the problems arising from the retention of a diplomatic mission accredited to a government which no longer exercises any local author-

48 With regard to the related problem of diplomatic missions to failed States, i.e. States without a government, see Riikka Koskenmäki, "Legal Implications Resulting from State Failure in the Light of the Case of Somalia", Nordic Journal of International Law 73 (2004), 1-36 at 8 ("State collapse does not thus automatically imply the recall of diplomatic missions or the severance of, or an end to, formal diplomatic relations between states."). It is also of interest to note that German courts held that the absence of a Somali national government did not automatically end the diplomatic mission or the diplomatic status of Somali diplomats in Germany: Judgement of the Federal Administrative Court of 29 February 1996, 5 C 23/95, Neue Juristische Woschenschrift 1996, 2744-2745; Order of the Higher Regional Administrative Court in Münster of 11 February 1992, 8 B 536/93, ibidem, 1992, 2043-2045, also reported in International Law Reports 94 (1994), 597-608.

49 See Charles Cheney Hyde, International Law Chiefly as Interpreted and Applied by the United States, 2nd edn., Boston 1947, vol. II, 1240; Jennings and Watts, supra n. 44, 1121-1122, 526, 527; Michael Richtsteig, Wiener Übereinkommen über diplomatische und konsularische Beziehungen, Baden-Baden 1994, 102; Georg Dahm/Jost Delbrück/Rüdiger Wolfrum, Völkerrecht, 2nd edn., vol. I/1, Berlin 1989, 295-296.

50 Inter-American Convention Regarding Diplomatic Officers, signed at Havana on 20 February 1928, 155 LNTS 259, Arts. 28, 25.

51 FRUS, 1917, Supplement 1, 656; Hyde, supra n. 49, vol. III, 1879.

52 See Hurst, supra n. 41, 232; Garner, supra n. 41, vol. I, 51-52.

53 The Times, 22 December 1936, 12. Germany and Japan which had recognized the Italian annexation of Ethiopia earlier had closed their Legations on 25 July 1936 and 30 November 1936, respectively. 
ity". ${ }^{54}$ Belgium recalled its Legation on 23 December 1936, ${ }^{55}$ and the United States Legation in Ethiopia continued to function until 31 Mach 1937, i.e. almost one year after the occupation and purported annexation of the country by Italy. ${ }^{56}$ In neither case were the foreign legations accredited to the Italian occupying authorities. (iii) On 6 April 1939, Italian troops invaded Albania. King Zog fled to Greece and the Albanian Government was dissolved on 16 April 1939. At the beginning of June 1939, the British Government confirmed that the British Minister was still in Durazzo, the capital of Albania, in his position "as a Minister", although it did not want to be drawn on whether he was there as "a Minister to the King of Albania". ${ }^{57}$

If the United States' argument that the end of the existence of the receiving State's government automatically entails the end of diplomatic status for the diplomatic agents "accredited" to it were taken at face value, all diplomats, irrespective of whether the receiving State is occupied or not, would lose their diplomatic status with each change of government, as their accreditation with that government would have lapsed. This argument is also undermined by the fact that only the heads of mission (ambassadors or nuncios), senior diplomatic agents (envoys, ministers and internuncios) and chargés d'affaires are formally accredited to the Head of State or the Minister of Foreign Affairs of the receiving State. ${ }^{58}$ No other diplomats are accredited; their appointment is simply notified to the Ministry of Foreign Affairs of the receiving State. Consequently, their (non-existent) accreditation could not have lapsed with the demise of the Government of Saddam Hussein. Even if the functions of diplomatic agents came to an end as a consequence of the demise of the government, they would still enjoy, as a matter of international law, privileges and immunities until they leave the country, or on expiry of a reasonable period to do so. ${ }^{59}$

The US position seems to be based on the assumption that the sole function of diplomatic agents is to maintain contact with the government of the receiving State; a function that comes to an end with the demise of

54 HC Debates, vol. 318, col. 2439, 16 December 1936.

55 The Times, 24 December 1936, 11.

56 FRUS, 1937, vol. II, 611.

57 See HC Debates, vol. 348, cols. 9-10: 5 June 1939.

58 See VCDR, Art. 14(1).

59 See Jennings and Watts, supra n. 44, 1122 n. 4; Lord Gore-Booth (ed.), Satow's guide to Diplomatic Practice, $5^{\mathrm{t}} \mathrm{h}$ edn. London 1979, 130, para. 15.25. See also VCDR, Art. 39(2). 
that government. ${ }^{60}$ It is apparent from the functions of diplomatic missions, set forth in Art. 3 VCDR, that diplomatic agents have important responsibilities on behalf of the sending State that do not depend on the continuing existence of the government that originally accredited the head or other senior members of the mission. A diplomatic mission, inter alia, represents the sending State in the receiving State; protects the interests of the sending State and its nationals in the receiving State, within the limits permitted by international law; ascertains by all lawful means conditions and developments in the receiving State, and reports thereon to the Government of the sending State; promotes friendly relations between the sending State and the receiving State, and develops their economic, cultural and scientific relations; and performs consular functions. As the occupying power temporarily takes over many of the duties of the government it has deposed, diplomatic missions have a continuing interest in performing their normal functions as best as they can under the condition of occupation. ${ }^{61}$ It may be argued that some of their functions, such as protecting the interests of the nationals of the sending State, become even more important during occupation. Diplomatic missions may render assistance to citizens who find themselves in difficult conditions as a result of armed conflict and occupation; help stranded citizens to return home by providing travel documents or money; negotiate with hostage takers; and represent citizens before the occupation authorities. In the case of the Iraqi occupation of Kuwait, the Security Council expressly "demand[ed] that Iraq... take no action to hinder the diplomatic and consular missions in the performance of their functions, including access to their nationals and protection of their person and interests" ${ }^{62}$

60 The Central Powers, which took a similar position to the United States in the case of Iraq, justified their request to withdraw foreign diplomats from occupied Bucharest by arguing, inter alia, that "since the departure of the Romanian Government they [the diplomatic representatives] can no longer exercise their diplomatic functions." See "Faits et Informations", Journal du droit international 44 (1917), 1883 (translation by the author).

61 Kirgis, supra n. 4, 2.

62 S/RES/667 (1990) of 16 September 1990, para. 4. 


\section{WithdRAWAL OF DiPlOMATIC MisSiONS AND THEIR MEMBERS FROM OCCUPIED TERRITORY}

\section{The Occupant's Right to Request the Withdrawal of Diplomatic Missions}

When a country is occupied by foreign troops, and its government either flees into exile, is dissolved, or functions under the supervision of the occupation authorities, the question arises whether foreign diplomatic missions may remain in the occupied territory or must follow the government into exile or return to their own country. The 1958 British Manual of Military Law on The Law of War on Land provides that if a State occupies another State, diplomatic agents accredited to the occupied State "may, if necessary, be compelled to withdraw to the State which they represent". ${ }^{63}$ Diplomatic practice and precedent supports the view that the occupant has a right to request the (temporary) withdrawal of diplomatic missions from the occupied territory ${ }^{64}$ When Prussia invaded Saxony at the end of August 1756, Frederick the Great ordered the French Ambassador to leave Dresden without delay. However, he allowed the secretary of the Embassy to function as chargé d'affaires for another three months until February 1757. ${ }^{65}$ Following the occupation of Luxembourg, on 4 August 1914 the German occupation authorities requested the French and Belgian Ministers to leave the country. ${ }^{66}$ Similarly, after the Central Powers had occupied Bucharest in December 1916, they requested neutral governments to withdraw their diplomats by 13 January $1917 .{ }^{67}$ During the Second World War, Germany requested the withdrawal of foreign diplomatic missions from all occupied territories. For example, on 1 July 1940, the German Foreign Office sent the following note to the Swiss legation in Berlin:

63 War Office, The Law of War on Land being Part III of the Manual of Military Law, London 1958, 196, para. 688 (emphasis added).

64 See Gerhard von Glahn, Law Among Nations, 5th edn., New York 1986, 693; Erik Castrén, The Present Law of War and Neutrality, Helsinki 1954, 224; Dahm/Delbrück/Wolfrum, supra n. 49, 295; Friedrich Berber, Lehbuch des Völkerrechts, vol. II, 2nd edn., Munich 1969, 132; Patrick Dallier and Alain Pellet, Droit International Public, 7th edn., Paris 2002, para, 460 at p. 751.

65 See Ernest Satow, A Guide to Diplomatic Practice, 2nd edn., London 1922, vol. I, 341, 363.

66 Garner, supra n. 41, vol. I, 44.

67 Garner, supra n. 41, vol. I, 52; Hurst, supra n. 41, 232-233. 
Upon the occupation of the entire territory of Norway, the Netherlands, Belgium, and Luxembourg by German troops, the lawful authority in these countries passed into German hands. Besides, the former governments of these States fled their country and thus no longer exercise lawful governmental authority. In view of these circumstances, the activities of the diplomatic missions which have been accredited to the former governments of these countries has lost its basis... The Foreign Office therefore requests the Swiss legation to ask its government to withdraw its diplomatic missions from Oslo, The Hague, Brussels and Luxembourg and to do so by 15 July of this year at the latest. The German Government is, for the time being, agreed that the consular missions remain in the said countries and territories and continue to exercise de facto their present functions. ${ }^{68}$

Similar notes were sent to all other diplomatic missions in Berlin. ${ }^{69}$ In no case did these requests meet with any protest on the part of neutral States. ${ }^{70}$ The Allies adopted the same practice. For example, the Instrument of Surrender of Italy, signed at Malta on 29 September 1943, provided in section 25(B): "The United Nations reserve the right to require the withdrawal of neutral diplomatic and consular officers from occupied Italian territory". ${ }^{71}$ After the occupation of Rome by Allied forces on 4-5 June 1944, enemy diplomats accredited to the Holy See who resided in the Italian capital under the Lateran Treaty were requested to move into the Vatican City by mid-day of 19 July 1944, or to leave Italy under safe conduct. The same procedure had been followed during the German occupation of Rome. ${ }^{72}$ Control Council Proclamation No. 2 of the four Al-

$68 D D S$, vol. 13, no. 324, 783. After the occupation of Poland in September 1939, the German government decided that all foreign diplomatic and consular officers must withdraw from Poland by 20 March 1940; see Ellery C. Stowell, "Vae Victis", American Journal of International Law 34 (1940), 310-312.

69 See e.g. for the United States: FRUS, 1941, vol. II, 748-749; Green Haywood Hackworth, Digest of International Law, Washington 1943, vol. VI, 391; Graham H. Stuart, American Diplomatic and Consular Practice, 2nd edn., New York 1952, 274; for the Vatican: Actes et documents du Saint Siège relatifs à la Seconde Guerre Mondiale 1939-1945, vol. 4, no. 14, 74. The Vatican argued that the papal nunciatures should be allowed to continue to operate in the occupied territories at least with regard to their ecclesiastiacal function; ibidem, no. 28,88 .

70 The Swiss Federal Council, noting that "there was obviously no other option, that to accept the facts", decided to recall its missions; see $D D S$, vol. 13, no. 324, 783 n. 1 and 1054. See also ibidem, vol. 13, 1054, 1055 and vol. 14, 1338. The Swiss diplomatic missions in the occupied countries were usually transformed into consulates and consulates-general.

71145 BFSP 280; Nouveau Recueil Général de Traités, 3rd series, vol. 41, 876.

72 FRUS, 1944, vol. IV, 1314-1315. 
lied Powers for occupied Germany also provided that: "the Allied Representatives may require the withdrawal from Germany of neutral diplomatic, consular, commercial and other officials and members of neutral service missions". ${ }^{73}$

The practice of occupying powers of expressly requesting third States to withdraw their diplomatic missions from the occupied territory further demonstrates that neither occupation, nor the exile or dissolution of the occupied State's government as such, ends the diplomatic status of foreign missions and their members.

On occasion, the occupant has also acted through the local government under its control. For example, during the Second World War, the Danish Government broke off diplomatic relations with neutral States on the instruction of the German occupation authorities. After US troops had invaded and occupied Grenada on 25 October 1983, ${ }^{74}$ the Governor-General, Sir Paul Scoon, delivered notes to the Soviet and Libyan Embassies on 1 November 1983, breaking off diplomatic relations and ordering all diplomatic personnel to leave Grenada the next day. ${ }^{75}$ The move came only days after the United States Government had unsuccessfully offered to the Soviet Government that it "would be happy to facilitate the evacuation of their diplomatic personnel from the island if they request it". ${ }^{76}$ At the same time, the Governor-General requested the $\mathrm{Cu}$ ban Government to reduce the personnel at the Cuban mission to one.

The right of the occupant to request the recall of individual foreign diplomatic agents or the (temporary) withdrawal of the diplomatic mission may be based on Art. 43 HR which gives the occupying power de facto authority to "take all the measures in his power to restore, and ensure, as far as possible, public order and safety" in the occupied territory. But for the recall request to be warranted under this provision, the continued presence of the diplomatic mission has to constitute a threat to public order and, especially, to the security interests of the belligerent

73 Enactments and Approved Papers of the Control Council and Coordinating Committee, Berlin 1945, vol. 1, 83.

74 On the "US occupation" of Grenada, see Eyal Benvenisti, The International Law of Occupation, Princeton 1993 (paperback edition, 2004), 168-171.

75 Parkerson, supra n. 16, 119 n. 522. See also Time Magazine [US Edition], 14 November 1983, 18; "49 Russians and 53 Cubans leave isle", New York Times, 5 November 1983, 6.

76 The offer was made on 28 October 1983; see "U.S. troops said to capture secret treaties in Grenada", United Press International, 31 October 1983, available at http://web.lexis-nexis.com/executive/ (last visited 25 July 2005). 
occupant. Such a threat cannot generally be assumed, as it can in the case of enemy States. It is argued that, for a recall request to be justified, there must be sufficient reason to suspect espionage, communication of military information to the enemy or other activities incompatible with diplomatic status. ${ }^{77}$ It is, however, admitted that in practice the occupant will have a wide margin of discretion in deciding upon any recall request.

As occupying power in Iraq, the United States would have been entitled under the laws of occupation to request the temporary withdrawal of foreign diplomatic missions in Baghdad. However, such a request might have seemed politically inopportune at the time, in view of the Security Council's appeal "to Member States... to assist the people of Iraq in their efforts to reform their institutions and rebuild their country, and to contribute to conditions of stability and security in Iraq". ${ }^{78}$ A request to withdraw diplomatic missions would have sent the wrong signal to an international community already highly critical of the US invasion of Iraq.

\section{The Withdrawal of Diplomatic Missions and Implied Recognition of Annexation}

The reaction of the international community in the case of Iraq's occupation of Kuwait does not call into question the right of the occupant to request States to withdraw their diplomatic missions from the occupied territory. On 2 August 1990, Iraq invaded Kuwait and six days later the Iraqi Government annexed the country, announcing that it had decided to "return the part and the branch, Kuwait, to the whole and origin, Iraq, in a comprehensive and eternal merger unity". ${ }^{79}$ On 9 August 1990, the 68 diplomatic missions in Kuwait City were informed that all diplomatic and consular missions in Kuwait were to close by 24 August $1990 .{ }^{80}$ In response, the Security Council on 18 August 1990 adopted resolution 664 (1990) "demand[ing] that the Government of Iraq rescinds

77 Talmon, supra n. 17, 160. See also the Opinion of the Legal Adviser of the US Department of State, dated 7 May 1936, that "the belligerent occupant... possesses an unquestioned right to regulate all intercourse between the territory under his control and the outside world." (Hackworth, supra n. 69,156$)$.

78 S/RES/1483 (2003) of 22 May 2003, para. 1.

79 Keesings's 1990, 37635. See also S/RES/666 (1990) of 9 August 1990, preambular para. 2.

80 See Interim Report to the Secretary-General by a United Nations mission assessing the loss of life incurred during the Iraqi occupation of Kuwait, as well as Iraqi practices against the civilian population in Kuwait, UN Doc. S/22536, 29 April 1991, 9, para. 40. 
its orders for the closure of diplomatic and consular missions in Kuwait and the withdrawal of the immunity of their personnel, and refrain from any such action in the future". ${ }^{81}$ Moreover, in resolution 667 (1990), the Council "demand[ed] that Iraq immediately and fully comply with its international obligations under... the Vienna Convention on Diplomatic Relations of 18 April 1961" and that "Iraq immediately protect the safety and well-being of diplomatic and consular personnel and premises in $\mathrm{Ku}-$ wait". ${ }^{82}$ These demands were reaffirmed in resolution 674 (1990). ${ }^{83} \mathrm{In}$ addition, the Council "demand[ed] that Iraq ensure the immediate access to food, water and basic services necessary to the protection and well-being of... the personnel of diplomatic and consular missions in Kuwait". ${ }^{84}$ This reaction of the Security Council must be seen against the background of Iraq's purported (illegal) annexation of Kuwait. According to Iraq, Kuwait no longer existed as a separate independent State, the territory having become a province of Iraq. There was therefore no longer any raison d'être for the activities of diplomatic missions in Kuwait. As far as the international community was concerned, the annexation was illegal and void. Iraq had no right in interfere in the diplomatic relations between Kuwait and third States. In resolution 662 (1990), the Security Council "decid[ed] that annexation of Kuwait by Iraq under any form and whatever pretext has no legal validity, and is considered null and void" and "call[ed] upon all States, international organizations and specialized agencies not to recognize that annexation, and to refrain from any action or dealing that might be interpreted as an indirect recognition of that annexation". ${ }^{85}$ The Council's demand to rescind the order for the closure of diplomatic missions in Kuwait can be seen as a response to Iraq's purported annexation of Kuwait. In a statement issued on 21 August 1990, the Twelve Member States of the EC declared:

The Community and its member states, in the light of their condemnation of the Iraqi aggression against Kuwait as well as of their refusal to recognise the annexation of that state to Iraq, firmly reject the unlawful Iraqi demand to close the diplomatic missions in Kuwait and reiterate their resolve

81 S/RES/664 (1990) of 18 August 1990, para. 3.

82 S/RES/667 (1990) of 16 September 1990, paras. 3, 4.

83 S/RES/674 (1990) of 29 October 1990, para. 6.

84 Ibidem, para. 5.

85 S/RES/662 (1990) of 9 August 1990, paras. 1 and 2. The decision that the annexation of Kuwait by Iraq is null and void was reaffirmed in S/RES/664 (1990) of 18 August 1990, para. 3. 
to keep those missions open in view also of the task of protecting their nationals. ${ }^{86}$

A similar statement was made by Romania. The Romanian Foreign Ministry spokesman said at a news conference in Bucharest on $30 \mathrm{Au}-$ gust 1990:

Romania has not recognized the annexation of Kuwait by Iraq, and as a result Romania does not recognize the juridical effects of this annexation, resulting from the military intervention. Therefore, our government decided to maintain our embassy in Kuwait even after the date of 24 August established by the occupying Iraqi authorities to close embassies in $\mathrm{Ku}$ wait, and we continue to maintain relations with the legitimate government of Kuwait. ${ }^{87}$

Some 25 States (including the United States, Canada, and eight European Union States) ignored the closure order, but their diplomatic agents were finally forced by unbearable living conditions - the Iraqi occupation authorities having cut off the missions from the water and electricity supply - to leave Kuwait. On 17 December 1990, the British Ambassador, as last diplomatic agent, left for London. However, States insisted that their missions, although temporarily unstaffed, remained open and that they continued to maintain diplomatic relations with $\mathrm{Ku}$ wait. ${ }^{88}$ It is submitted that States' insistence to keep their diplomatic missions open was more a political gesture to underscore their refusal to accept the validity of the attempted annexation than a legal necessity; in strictly legal terms, a diplomatic protest would have sufficed to reserve their legal position. ${ }^{89}$ There are several precedents where States have withdrawn their diplomatic missions from occupied territory while insisting that they did not recognize the annexation of that territory: (i) On 9

86 Bulletin of the European Communities, 7/8B1990, 124. See also the statement of the French Foreign Minister Roland Dumas in an interview with Le Monde on 10 August 1990 regarding the Iraqi demand for the closure of foreign diplomatic missions in Kuwait: "No. This would mean recognizing the annexation of that country by Iraq and endorsing the aggression which it has committed"; see Jean-Pierre Puissochet, "Relations diplomatiques et protection des nationaux", in Brigitte Stern (ed.), Les aspects juridiques de la crise et de la guerre du Golfe, Paris 1991, 93-106 at 98-99 (translation by the author).

87 BBC SWB, 3rd Series EE/0860 A4/1, 4 September 1990.

88 See Talmon, supra n. 17, 162 with further references.

89 See Marc Weller, "The Kuwait Crisis: A Survey of Some Legal Issues", African Journal of International and Comparative Law 3 (1991), 1-40 at 18. 
May 1936, Italy annexed Ethiopia. The British Ambassador in Rome informed the Italian Ministry of Foreign Affairs on 21 December 1936 of "the decision of His Majesty's Government to withdraw the British Legation at Addis Ababa and to substitute for it a Consulate-General". ${ }^{90}$ Great Britain and other States insisted that this action did not involve de jure recognition of the annexation of Ethiopia. In fact, Great Britain accorded de jure recognition only some two years later, on 16 November 1938.91 (ii) On 16 March 1939, Germany established the Protectorate of Bohemia and Moravia in parts of the former Czechoslovakia. On 22 May 1939, the British Under-Secretary of State for Foreign Affairs, Mr Butler, declared that the withdrawal of His Majesty's Legation at Prague does not imply recognition of the German annexation of Bohemia and Moravia. $^{92}$ (iii) After the German annexation of Austria on 13 March 1938, foreign States were requested to close their diplomatic missions in Vienna. On that occasion, the United States informed Germany that it found itself "under the necessity as a practical measure" of closing its legation; the United States Government never took the position that Austria was legally absorbed into the German Reich. ${ }^{93}$ (iv) On 11 August 1940, the Soviet Foreign Commissar Molotov communicated the following note to foreign missions in Moscow:

Lithuania, Latvia, and Estonia have by decision of the Supreme Soviet been incorporated in the territory of the Soviet Union and therewith have become a part of the Soviet Union. The direct diplomatic relations of Lithuania, Latvia, and Estonia are terminated. The Soviet Union accordingly expects that... legations in Kaunas, Riga, and Tallin will be liquidated on or before August 25. Consulates must likewise be liquidated on or before September $1 .{ }^{94}$

90 HC Debates, vol. 319, col. 32-33: 19 January 1937; The Times, 22 December 1936, 12.

91 See Arnold D. McNair, "Municipal Effects of Belligerent Occupation", Law Quarterly Review 57 (1941), 33-73 at 53.

92 HC Debates, vol. 347, cols. 1891-1892: 22 May 1939. See also Jennings and Watts, supra n. 44,1123 n. 4.

93 FRUS, 1938, vol. II, 76. See also U.S. ex rel. Zdunic v. Uhl, 47 F.Supp. 520 (D.C.N.Y. 1942), also reported in Annual Digest and Reports of Public International Law Cases 1941-1942, No. $164,530-534$ at 534 .

94 See $D G F P$, Series D, vol. X, No. 328, 466. 
All States withdrew their diplomatic and consular missions but, with the exception of Germany, Italy and Sweden, did not accord de jure recognition to the Soviet annexation of the Baltic States. ${ }^{95}$

It may be concluded that the Security Council, by adopting binding resolutions under Chapter VII of the Charter, created what Theodor Meron called "a lex specialis for foreign embassies in Kuwait", ${ }^{96}$ overruling the customary international law right of the occupying power to request the withdrawal of foreign diplomats. As a consequence of these Security Council resolutions, foreign States were thus acting lawfully when they refused to withdraw their diplomatic personnel from Kuwait and close their missions in the occupied country.

\section{Temporary Continuation of Diplomatic Privileges and Immunities}

The occupant must allow foreign diplomatic agents a "reasonable period" in which to withdraw from the occupied territory. ${ }^{97}$ There is no minimum period in international law; much will depend on the circumstances of the particular case. For reasons of legal certainty, occupying powers have usually fixed a certain date by which diplomatic mission must be closed. In most cases, they have allowed at least a fortnight to do so. The occupant must respect the status of the diplomatic mission and the privileges and immunities of foreign diplomats until they leave the country, or until the date set to do so. ${ }^{98}$ This applies even where the government of the occupied States has been dissolved. After the incorporation of Austria into the German Reich on 13 March 1938 and the dissolution of the Austrian Government, foreign States were requested to close their legations in Vienna by 10 April 1938. ${ }^{99}$ On 22 March 1938, the German Government gave assurance that "diplomatic privileges would be scrupulously observed for the present". ${ }^{100}$ Similarly, after the

95 See Karl-Heinz Mattern, Die Exilregierung,Tübingen 1953, 53.

96 Theodor Meron, "Prisoners of War, Civilians and Diplomats in the Gulf Crisis", American Journal of International Law 85 (1991), 104-109 at 109.

97 Cfr. VCDR, Art. 39(2).

98 See Dahm/Delbrück/Wolfrum, supra n. 49, 295; Jennings and Watts, supra n. 44, 1116, 517; Morris Greenspan, The Modern Law of Land Warfare, Berkeley 1959, 580-581. See also Lasa Oppenheim, International Law. A Treatise, vol. I (8th edn., ed. by Hersch Lauterpacht), London 1955, 808, ' 399; Antonio Sanchez de Bustamente y Sirven, Droit International Public, Paris 1937, vol. IV, 386.

99 FRUS, 1938, vol. I, 456.

100 Ibidem, 460. 
German annexation of Bohemia and Moravia, foreign missions in Prague were ordered to close by 25 May 1939. On 20 March 1939, the British Government confirmed that its Legation at Prague still enjoyed "extra-territo- riality", despite the fact there was no longer any Czechoslovak Government to which the mission could be accredited. ${ }^{101}$

If foreign diplomats fail to leave the occupied territory within a reasonable period of time, they will lose their diplomatic privileges and immunities and will be treated as any other foreign private person. If their sending State has normal diplomatic representation in the occupying State, they do not qualify as "protected persons" under the Fourth Geneva Convention and may be deported to their home country. While in the occupied territory, they will benefit only from the limited protection extended under Part II of the Convention, which applies to the whole of the population of the occupied territory. With respect to acts performed in the exercise of their functions as a member of the diplomatic mission they will, however, continue to enjoy functional immunity. ${ }^{102}$ In the absence of diplomatic relations between the sending and occupying States, the now former diplomats qualify as protected persons under the Convention. ${ }^{103}$ The deportation of protected persons is prohibited. ${ }^{104}$ In this case, the former diplomats may be interned or placed in assigned residence in the occupied territory, if the security of the occupying power makes such a step absolutely necessary. ${ }^{105}$

If foreign diplomats cannot leave the occupied territory and return to their home country due to the general military situation, they may be interned in a safe and suitable place, with due regard for their diplomatic status. ${ }^{106}$

\section{Provision of Transport Facilities}

Under Art. 44 VCDR, "the receiving State must, even in the case of armed conflict, grant facilities in order to enable persons enjoying privileges and immunities... to leave at the earliest possible moment. It must, in particular, in case of need, place at their disposal the necessary means 
of transport for themselves and their property." Considering the special situation of military occupation with its inherent restrictions on movement and limitations of public transport, it is submitted that this obligation applies even more to an occupying power. On 17 October 1990, the British Government made the following statement with regard to eight diplomatic service personnel of the British Embassy in Kuwait: "Under Article 44 the Iraqis were required, even in the case of armed conflict, to grant facilities to enable persons enjoying privileges and immunities to leave at the earliest possible moment. In neither case had they fulfilled their obligations". ${ }^{107}$

In resolution 674 (1990), the Security Council also demanded that Iraq "permit and facilitate the immediate departure from Kuwait... of those third-State nationals, including diplomats and consular personnel, who wish to leave". ${ }^{108}$ These demands were in line with earlier practice. Occupying powers have usually provided special facilities for the evacuation of foreign diplomats and their property. The neutral diplomats left Bucharest on 13 January 1917 on a special train put at their disposal by the Central Powers. ${ }^{109}$ In April 1917, after the break in diplomatic relations between the United States and Germany, the German occupation authorities in Belgium provided a special train to transport the US Minister to Brussels and his Legation staff to Switzerland. ${ }^{110}$ In November 1936, the Italian occupation authorities in Ethiopia provided transport for the British Legation Guard in its removal from Addis Ababa. ${ }^{111}$ On 15 July 1940, a special train conveyed all the personnel of the foreign legations in the Netherlands to Switzerland. ${ }^{112}$ More recently, in November 1983, the personnel of the Soviet and Libyan missions in US-occupied Grenada was flown by US military plane to Mexico and Barbados respectively. ${ }^{113}$

107 "United Kingdom Materials on International Law 1990", British Year Book of International Law 61 (1990), 541.

108 S/RES/674 (1990) of 29 October 1990, para. 4.

109 Hurst, supra n. 41, 233; "Faits et Informations", Journal du droit international 44 (1917), 1883.

110 FRUS, 1917, Supplement 1, 657-660.

111 See HC Debates, vol. 318, col. 818: 30 November 1936.

112 "Sixteenth Report of the Permanent Court of International Justice (June 15th, 1939-December 31, 1945)", PCIJ Series E, No. 16, 10.

113 Parkerson, supra n. 16, 119 n. 522; Time Magazine [US Edition], 14 November 1983, 18; Department of State Bulletin, January 1984, 92. 


\section{Obligation of the Occupant to Protect the Vacated Mission Premises}

If a diplomatic mission has been temporarily withdrawn at the request of the occupying power, the occupying power is under an obligation to respect and protect the premises of the mission, together with its property and archives. ${ }^{114}$ On 13 December 1990, when the US Ambassador to Kuwait and his staff evacuated the American Embassy in Kuwait City, White House Press Secretary Marlin Fitzwater told reporters that the United States had "notified the Iraqi government that we hold them responsible for the protection of the physical facility". ${ }^{115}$ Similarly, when Libya recalled its diplomatic personnel from Iraq, the Libyan General People's Committee for African Unity Secretariat declared that "the Great Jamahiriyah holds the occupying authority responsible for the protection of... the bureau and its contents". ${ }^{116}$

\section{APPLICATION OF THE VIENNA CONVENTION ON DiPLOMATIC RELATIONS TO DIPLOMATIC MiSSIONS IN OCCUPIED TERRITORY?}

The Vienna Convention on Diplomatic Relations does not address the question of diplomatic missions and their members in occupied territory; rather, it regulates in general terms the legal relationship between the "receiving State" of a diplomatic mission and the "sending State". The question that arises is whether the Vienna Convention also applies between the occupying power and the sending State, i.e. whether the occupying power is bound by the Convention in its dealings with foreign diplomatic missions in occupied territory. This section deals first with the practice of States on that matter and then asks on what basis the Convention can be applied to occupying powers.

$114 C f r$. VCDR, Art. 45(a).

115 "Embassy Staff Leaves Kuwait; U.S. Ambassador, 4 Others End 4 Months Under Siege", Washington Post, 14 December 1990, A1. For the similar statement of the State Department spokesman, see American Foreign Policy: Current Documents 1990, Doc. No. 359, 554 ("We hold them responsible for protecting the property and premises of the U.S mission... And we hold them responsible for any loss or damage to this property.").

116 "Libya Radio announces severing of diplomatic ties with Iraq", BBC Monitoring International Reports, 1 June 2003, available at http://web.lexis-nexis.com/executive/ (last visited 27 July 2005). 


\section{Occupying Powers and the Vienna Convention of Diplomatic Relations: Three Salient Cases}

Diplomatic practice in three more recent cases of military occupation shows that States seem to be of the opinion that the Vienna Convention is applicable to occupying powers. The cases in point are the US occupation of Grenada in 1983, the US occupation of Panama in 1989, and the Iraqi occupation of Kuwait in 1990. While the United States rejected the notion that it was an "occupying power" in these cases, ${ }^{117}$ a majority of other States considered that it had illegally intervened in and, albeit briefly, occupied Grenada and Panama. ${ }^{118}$

\section{A. The US Occupation of Grenada}

On 25 October 1983, some 8,000 US troops, reinforced by 300 soldiers from neighbouring Caribbean islands, landed in Grenada. In three days, the force established complete control over the island. By mid-December, after the appointment of a new government, the bulk of the US forces left Grenada. ${ }^{19}$ According to Soviet accounts, a US military patrol briefly detained the Soviet Ambassador to Grenada during the occupation and searched his official vehicle; US military contingents blockaded the Soviet Embassy, which was cut off from the outside world, deprived of all means of communication and shut off from the electricity and wa-

117 Responding to the Vatican's description of the United States as an occupying power in Panama, the US State Department spokesman said: "We are down there with the consent of the government of Panama, the legitimately elected leaders of Panama. That means we're not an occupying power" ("Vatican sees 'US occupation' of Panama; Troops fire on Nicaraguan Embassy; US invasion of Panama", The Boston Globe, 30 December 1989, 1).

118 For Grenada, see A/RES/38/7 (1983) of 2 November 1983, para. 1 ("deeply deplores the armed intervention in Grenada which constitutes a flagrant violation of international law") and para. 4 ("calls for... the immediate withdrawal of foreign troops from Grenada"). The Resolution was adopted with 106 States in favour, eight against, and 25 abstentions. A similar resolution in the Security Council was not adopted because of the negative vote of the United States; 11 States had voted in favour and three had abstained; for the debates in the General Assembly and the Security Council, see United Nations Yearbook 1983, 211-217. For Panama, see A/RES/44/240 (1989) of 29 December 1989, para. 1 ("strongly deplores the intervention in Panama by the armed forces of the United States, which constitutes a flagrant violation of international law"), para. 2 ("demands the withdrawal from Panama of the armed invasion forces of the United States"). The Resolution was adopted with 75 States in favour, 20 against, and 39 abstentions). A similar resolution was not adopted by the Security Council because of the negative vote of three permanent members; for the debates in the Security Council and the General Assembly, see United Nations Yearbook 1989, 174-176.

119 For a detailed account and further references, see Benvenisti, supra n. 74, 168-171. 
ter supply. When the personnel of the Soviet Embassy left Grenada, "representatives of the occupying United States forces" searched the Embassy's official diplomatic consignment and the personal luggage of Soviet diplomats. In a letter of 30 November 1983 addressed to the Secretary-General of the United Nations, the USSR charged that the United States' occupying forces in Grenada had violated the Vienna Convention on Diplomatic Relations. The information transmitted by the USSR reads in part:

Despite its obligations under international law and despite repeated assertions concerning its adherence to the principles and norms of the Vienna Convention on Diplomatic Relations, the United States of America has recently committed criminal acts against the Soviet diplomatic mission... in Grenada...

The above-mentioned United States' actions against the Soviet diplomatic mission and its personnel are unprecedented. Under international law and the Vienna Convention on Diplomatic Relations, it is impermissible to breach the inviolability and security of diplomatic missions, to threaten the lives of their personnel or to carry out against them acts of the kind described above. ${ }^{120}$

This statement by the Soviet Government indicates that the USSR considered the United States bound by the Vienna Convention with regard to its diplomatic mission in Grenada, although the United States, strictly speaking, was not the "receiving State" of the mission.

\section{B. The US Occupation of Panama}

On 20 December 1989, the United States dispatched some 24,000 troops into Panama to overthrow the Government of Manuel Antonio Noriega. Although the Panamanian Defence Force resisted the US invasion, the US forces quickly managed to secure control over Panama. Less than an hour before the launch of the invasion, at a US military base in the Panama Canal zone, an alternative Panamanian Government, headed by Guillermo Endara, was sworn into office and immediately recognized by the United States as the legitimate Government of Panama. ${ }^{121}$ By

120 UN Doc. A/38/655, 2 December 1983, Annex. See also “Soviet Protest at 'Bandit Attack' on Embassy in Grenada", BBC Summary of World Broadcasts, SU/7478/A1/1, 31 October 1983.

121 For a detailed account and further references, see Benvenisti, supra n. 74, 171-173. 
mid-January 1984, US combat forces began to withdrew, although US forces remained in Panama in order to support the newly installed Panamanian Government. During the US occupation, several incidents occurred involving foreign diplomatic missions in Panama.

On 21 December 1989, in an attempt to prevent General Noriega and his associates from seeking diplomatic asylum in a friendly foreign embassy in Panama City, US troops surrounded the Papal Nunciature and the Cuban, Libyan, and Nicaraguan embassies, as well as the Peruvian ambassador's residence. US soldiers established checkpoints around these embassies and surrounded them with barbed wire. The Nicaraguan Foreign Minister condemned these actions by "United States occupation troops in Panama" and "demanded the immediate withdrawal of United States troops from the area surrounding the Nicaraguan Embassy and assurances that the interventionist forces, which are exercising illegal de facto control of parts of Panama City, will respect the privileges and immunities set forth in the Vienna Convention on Diplomatic Relations". ${ }^{122}$

On 24 December 1989, US forces arrested the First Secretary of the Cuban Embassy, outside the embassy premises. According to the Cuban Ambassador to Panama the action "was in violation of the Vienna Convention". ${ }^{123}$ This view was shared by the USSR, who described the detention of the Cuban diplomat by "US occupation forces" as a violation of Article 29 of the Vienna Convention of Diplomatic Relations. ${ }^{124}$ Referring to this and another incident on 15 January 1990, when US troops arrested the Cuban Ambassador and three other diplomats, Soviet Foreign Ministry spokesman Vadim Perfilyev told a press briefing:

Continuing acts of provocation by US troops against Cuban diplomats in Panama are an indication of gross violation by the USA of the basic norms of international law concerning foreign diplomatic representatives. We again draw the attention of the US administration to the inadmissibility of

122 Letter dated 21 December 1989 from the Permanent Representative of Nicaragua to the United Nations addressed to the Secretary-General, UN Doc. A/44/907-S/21046, 21 December 1989, Annex. For the Nicaraguan view of events, see Letter dated 27 December 1989 from the Permanent Representative of Nicaragua to the United Nations addressed to the Secretary-General, UN Doc. A/44/910-S/21059, 27 December 1989, Annex.

123 "Panama: Cuban Ambassador says arrest of embassy official a "provocation", BBC Summary of World Broadcasts, ME/0650/D/ 1, 30 December 1989.

124 "Cuban diplomats detained in Panama-Soviet spokesman", TASS, 29 December 1989; "USSR spokesman on US actions against Cuban embassy", TASS, 26 December 1989; both available at http://web.lexis-nexis.com/executive/ (last visited 22 July 2005). 
violating respective provisions of the Vienna Convention guaranteeing personal immunity of diplomatic agents, who are not subject to arrest or detention in any form. ${ }^{125}$

The most serious incident occurred on 29 December 1989, when US troops forced entry into the residence of the Nicaraguan Ambassador to Panama and searched the residence. ${ }^{126}$ They discovered a large number of weapons, which were later returned once the status of the premises had been established. In a communiqué circulated on 30 December 1989, the Rio Group of States called upon US troops to respect the immunity of diplomats accredited in Panama, the immunity which is provided for by the Vienna Convention on Diplomatic and Consular Relations. ${ }^{127}$ The Permanent Council of the Organization of American States declared "that the serious events that took place are... a violation of the privileges and immunities recognized under international law and codified in the Vienna Convention on Diplomatic Relations". ${ }^{128}$ On 17 January 1990, the United States vetoed a draft Security Council resolution on the violation of diplomatic immunities in Panama. Thirteen States voted for the resolution, and only the United Kingdom abstained. Operative paragraph 1 of the draft resolution declared "that the serious events that took place [on 29 December 1989] are, as has been acknowledged, a violation of the privileges and immunities recognized under international law and codified in the Vienna Conventions on Diplomatic and Consular Rela-

125 "Soviet spokesman blasts US harassment of Cuban diplomats", TASS, 15 January 1990, available at http://web.lexis-nexis.com/executive/ (last visited 22 July 2005).

126 On 31 December 1989, US troops also searched the private residence of two Nicaraguan diplomats. For the Nicaraguan view of events, see UN Docs. A/44/912-S/21064, 2 January 1990; S/21066, 3 January 1990. For the US version of events, see UN Doc. S/PV.2905, 17 January 1990, 26-28.

127 "Rio Group urges US to respect diplomatic immunity in Panama", TASS, 30 December 1989; "Latin American countries ask for respect of the norms on international rights", Xinhua General Overseas News Service, 30 December 1989, both available at http://web.lexis-nexis.com/executive/ (last visited 22 July 2005). The Rio Group consists of Argentina, Brazil, Colombia, Mexico, Peru, Uruguay, and Venezuela.

128 OEA/Ser.G, CP/RES.536 (802/90), 8 January 1990, para. 1. The Permanent Council also considered "the obligation of States to respect fully the privileges and immunities granted to diplomatic missions and agents by international law, as codified in the Vienna Convention on Diplomatic Relations of April 18,1961, especially with regard to the inviolability of the premises and residences of diplomatic missions and the immunity, safety and personal integrity of diplomatic agents" (ibidem, preambular para. 1). The vote was 19 to 0, with six countries joining the United States in abstaining. 
tions". ${ }^{129}$ The US representative on the Security Council acknowledged that the action was "not consistent with diplomatic privileges and immunities." He said:

The Vienna Convention on Diplomatic Relations clearly sets forth the inviolability of diplomatic premises. The United States fully supports and abides by that Convention... Following its full investigation of the incident of 29 December... [o]n 31 December new, detailed instructions were issued to United States military forces and civilian personnel in Panama. These instructions were designed to ensure that Embassy premises, accredited diplomats and their private residences are accorded the diplomatic privileges and immunities to which they are entitled under the Vienna Convention on Diplomatic Relations. The instructions explicitly quote the pertinent articles of the Vienna Convention, which the United States not only fully accepts but supports. ${ }^{130}$

During the debate in the Security Council, the representative of Nicaragua spoke of "actions violating the Vienna Conventions on Diplomatic and Consular relations in particular and international law in general". ${ }^{131}$ The Canadian delegate referred to "a breach of international conventions resulting from the actions of its forces" and "a violation of the diplomatic immunities and privileges recognized under international law and codified in the Vienna Convention on Diplomatic Relations". ${ }^{132}$ For the Finnish representative, the actions constituted "a violation of general principles of international law, as enshrined in the Vienna Convention on Diplomatic Relations in particular". ${ }^{133}$

\section{The Iraqi Occupation of Kuwait}

On 2 August 1990, Iraq invaded Kuwait. The country was under Iraqi occupation until its liberation by US-led coalition forces on $27 \mathrm{Feb}$ ruary 1991. ${ }^{134}$ On 9 August 1990, the Iraqi occupation authorities informed the diplomatic missions in Kuwait City that they were to close by

129 UN Doc. S/21084, 16 January 1990. The draft resolution had been introduced by Colombia, Cote d'Ivoire, Cuba, Democratic Yemen, Ethiopia, Malaysia and Zaire.

130 UN Doc. S/PV.2905, 17 January 1990, 21, 22, 28.

131 Ibidem, 3. See also ibidem., 9.

132 Ibidem, 37.

133 Ibidem, 38.

134 For a brief account, see Benvenisti, supra n. 74, 150-151. 
24 August 1990. ${ }^{135}$ When some 25 missions defied the closure order, the Iraqi authorities cut them off from food, water and electricity supplies and interrupted their telephone communications. On several occasions, Iraqi forces detained foreign diplomats, forcibly entered the premises of diplomatic missions, closed the missions and relocated their members to Baghdad, where they were held hostage. ${ }^{136}$

The actions of the Iraqi authorities and occupying forces were widely condemned by States as a "serious violation of the Vienna Conventions on Diplomatic and Consular Relations". ${ }^{137}$ The Twelve Member States of the EC issued the following statement on 14 September 1990:

The Community and its Member States denounce the very grave violation of the provisions of the 1961 Vienna Convention, which Iraq has subscribed to, perpetrated by the Iraqi occupying forces in Kuwait when they broke into the premises of the French and Dutch Embassies and took away French nationals, one of them a diplomat. ${ }^{138}$

Similarly, Egypt stated in the $6^{\text {th }}$ Committee of the General Assembly that "Iraq had responsibility to ensure the protection, security and the safety of missions and diplomatic personnel accredited to Kuwait and to respect their diplomatic immunity under the Vienna Conventions, of which it was a signatory". ${ }^{139}$ On 18 December 1990, the British Embassy in Baghdad delivered a note to the Government of Iraq in which the British Government protested against the illegal actions of the Iraqi authorities which obliged the temporary withdrawal of the Ambassador and his staff from the British Embassy in Kuwait. The note reads, in part, as follows:

The British Embassy and its staff are duly accredited to the legitimate Government of Kuwait, and as such are entitled under the Vienna Conven-

135 See supra at n. 80 .

136 For a detailed account of events, see Seibt, supra n. 14, 452.

137 See e.g. UN Docs. A/C.6/45/SR.7, 8 October 1990, 9-10, para. 40 (China); ibid., 16, paras. 74-75 (Mexico); A/45/512-S/21783, 17 September 1990 (EC); S/21773, 16 September 1990 (Luxembourg); S/21769, 15 September 1990 (Norway); S/2759, 15 September 1990 (Germany). See also S/RES/674 (1990) of 29 October 1990, para. 3.

138 Bulletin of the European Communities, 9B1990, 81 (emphasis added).

139 UN Docs. A/C.6/45/SR.7, 8 October 1990, 3, para. 9 (emphasis added). See also Letter dated 27 August 1990 from the Permanent Representative of Egypt to the United Nations addressed to the Secretary-General, UN Doc. S/21674, 31 August 1990, Annex. 
tion on Diplomatic Relations to the protection, privileges and immunities there specified. The Government of Iraq and the Iraqi occupation authorities are obliged to respect and observe these rights. Iraq cannot, by its illegal occupation of Kuwait, claim to extinguish or infringe the rights which the British Government and their Embassy in Kuwait enjoy under the provisions of the Vienna Convention. By interfering with the functioning of the British Embassy in Kuwait, and thus necessitating the temporary withdrawal of the Ambassador and his staff, Iraq has violated the most fundamental provisions of the Vienna Convention on Diplomatic Relations, to which Iraq is a party. The United Kingdom will hold Iraq responsible for the above violations of the Vienna Convention. ${ }^{140}$

Thus there is ample evidence that States consider the occupying power bound by the Vienna Convention on Diplomatic Relations; ${ }^{141}$ the question that remains is on what basis the Convention is applied to the occupying power.

\section{Legal Basis for the Application of the Vienna Convention of Diplomatic Relations}

The Vienna Convention on Diplomatic Relations can be applied to the occupying power in two ways. First, the occupying power could be bound by the Convention because it is itself a party to it. The statements of the EC Member States, Egypt and the United Kingdom in the case of the Iraqi occupation of Kuwait that Iraq "has subscribed", is "a signatory", or "a party" to the Convention seem to point in this direction. Currently, 183 States are parties to the Convention, including Iraq and the United States. ${ }^{142}$ It is well established that armed conflict does not have any effect on the Vienna Convention on Diplomatic Relations. ${ }^{143}$ How-

140 Letter dated 18 December 1990 from the Permanent Representative of the United Kingdom of Great Britain and Northern Ireland to the United Nations addressed to the Secretary-General, UN Doc. S/22020, 19 December 1990, Annex (emphasis added).

141 See also with regard to the US occupation of Iraq the statement by the Russian Foreign Ministry spokesman: "Any attack against our embassy will be considered a serious violation of the Vienna Convention on diplomatic privilege and immunity." ("Iraq: Russia remains unconvinced of US success", IPS-Inter Press Service, 10 April 2003, available at http://web.lexis-nexis.com/executive/ (last visited 22 July 2005).

142 For a list of parties to the Convention, see http://untreaty.un.org (last visited 25 July 2005).

143 See "The effect of armed conflict on treaties: an examination of practice and doctrine. Memorandum by the Secretariat", UN Doc. A/CN.4/550, 1 February 2005, p. 25, para. 36. See also the 
ever, there are several problems with the application of the Vienna Convention on the basis that the occupant is a party to it. Multilateral treaties can generally be divided into treaties which create obligations between all the parties, i.e. treaties creating obligations erga omnes, and those which create a multitude or web of bilateral legal relationships. ${ }^{144}$ The Vienna Convention on Diplomatic Relations is, by its very nature, a multilateral treaty creating bilateral legal relationships between the sending State and the receiving State of a diplomatic mission. ${ }^{145}$ Thus the Convention, as a rule, establishes rights and duties for the sending and the receiving State only. ${ }^{146}$ The occupant does not formally qualify as the "receiving State" with regard to foreign diplomatic missions in the occupied territory. Nor does it take on the role of receiving State by virtue of occupation. Modern State practice does not support Lieber's view of 1863 that the "occupying power usually recognizes them [neutral States' diplomats] as temporarily accredited to itself". ${ }^{147}$ The occupation authorities in Iraq expressly declared: "We as the coalition provisional authority are not taking accreditations". ${ }^{148}$ Even if this was the case, what would be the legal situation if the occupying power expressly refused to recognize them as accredited to itself? One might argue that the term "receiving State" must be interpreted more widely to include foreign diplomatic missions not just in the territory of the occupying State but "in territories under its jurisdiction." In resolution 43/167 of 9 December 1988 on effective measures to enhance the protection, security and safety of diplo-

"First report on the effects of armed conflicts on treaties by Mr. Ian Brownlie, Special Rapporteur", UN Doc. A/CN.4/552, 21 April 2005, pp. 36-37, para. 111.

144 Cfr. Barcelona Traction, Light and Power Company, Limited, Judgment, ICJ Reports 1970, 3 at 32, paras. 33, 34. See also VCLT, Art. 60(2). See generally, Bruno Simma, Das Reziprozitätselement im Zustandekommen völkerrechtlicher Verträge, Belin 1972, 63-64, 66, 153-155 and 205-207.

145 Alfred Verdross and Bruno Simma, Universelles Völkerrecht, 3rd edn., Berlin 1984, ' $539 \mathrm{n}$. 24, ' 733 at 469, ' 813 at 518; Dahm/Delbrück/Wolfrum, supra n. 49, 285; Seibt, supra n. 14, 446.

146 Only VCDR, Art. 40 imposes obligations on "third States", but even these obligations arise in the context of relations between the sending and the receiving State.

147 For the Lieber Code, see supra at n. 40. But see also Hans-Peter Gasser, "Protection of Civilian Population", in: Dieter Fleck (ed.), The Handbook of Humanitarian Law in Armed Conflict, Oxford 1995, 209-292 at 241 who, in the context of protected persons in the sense of GC IV, Art. 4, speaks of "diplomatic representatives accredited by the occupying power" (emphasis added). GC IV, Art. 4(2) speaks, however, of "diplomatic representation in the State in whose hands they are".

148 "US-led administration says no plans to accredit foreign diplomats", Agence France Presse-English, 31 May 2003, available at http://web.lexis-nexis.com/executive/ (last visited 22 June 2005). 
matic and consular missions and representatives, the General Assembly urged States "to ensure, in conformity with their international obligations, the protection, security and safety of the [diplomatic and consular] missions, representatives and officials... officially present in territories under their jurisdiction". ${ }^{149}$ The European Court of Human Rights (ECtHR) has held that, for the purposes of the European Convention on Human Rights (ECHR), ${ }^{150}$ territory under a State's jurisdiction is not restricted to a State's national territory, but may include areas under its effective control as a consequence of military occupation. ${ }^{151}$ It should be noted that the ECHR in Art. 1 expressly provides that the "High Contracting Parties shall secure to everyone within their jurisdiction the rights and freedoms defined in Section 1 of this Convention." No such provision can be found in the Vienna Convention on Diplomatic Relations. There is also another problem with extending the occupying power's treaty obligations to the occupied territory. According to Art. 29 of the Vienna Convention on the Law of Treaties (VCLT): 152 "a treaty is binding upon each party in respect of its entire territory." Any territorial extension of the treaties of the occupant to the territory under occupation would, as a rule, imply the extension of its territorial sovereignty to that territory and would thus amount to the (illegal) annexation of the occupied State. ${ }^{153}$ In the occupied territory, the occupant exercises neither its own sovereign authority nor that of the occupied State. It rather exercises de facto authority based on its effective control of the occupied territory, which is recognized and limited by the laws of war.

149 A/RES/43/167 of 9 December 1988, para. 3. See also A/RES/57/15 of 19 November 2002, para. 3; A/RES/59/37 of 2 December 2004, para. 3.

150 Convention for the Protection of Human Rights and Fundamental Freedoms, done at Rome on 4 November 1950, 213 UNTS 221.

151 See e.g. Loizidou v. Turkey (preliminary objections), judgment of 23 March 1995, Series A no. 310, 23, '62; Loizidou v. Turkey judgment of 18 December 1996, Reports of Judgments and Decisions 1996-VI, 2234, '52; Bankovic and Others v. Belgium and 16 other Contracting States, Decision of 12 December 2001 [GC], Application No. 52207/99, "70-71; Issa and Others v. Turkey, Judgment of 16 November 2004, Application No. 31821/86, "68-74. But see also the decision of the English High Court in $R$. (on the application of Al-Skeini) v. Secretary of State for Defence (QBD (Admin) 2004), [2005] 2 WLR 1401 at 1473-1482 which, on the basis of the "espace juridique doctrine" which was first recognized by the ECtHR in Bankovic, ' 80 , limited any extra-territorial application of the ECHR to territory of parties to the Convention.

152 Vienna Convention on the Law of Treaties, opened for signature on 23 May 1969, 1155 UNTS 331.

153 See Gasser, supra n. 147, 245-246. An exception is treaties whose scope of application is based on the parties' "jurisdiction" rather than their territory; see ECHR, Art. 1. 
Secondly, the occupying power could be bound by the Vienna Convention because the occupied State is a party to the Convention and the treaty obligations of the occupied State pass to the occupying power. ${ }^{154}$ It could be argued that the occupant is bound by treaty obligations as part of the domestic law of the occupied State. According to Art. $43 \mathrm{HR}$, the occupant "shall take all the measures in his power to restore, and ensure, as far as possible, public order and safety, while respecting, unless absolutely prevented, the laws in force in the country." The laws in force in the occupied country will usually include the provisions of the Vienna Convention on Diplomatic Relations, which in most States has been transformed into domestic law. ${ }^{155}$ Article 43 HR only imposes limitations on the legislative and executive powers of the occupier; it does not subject the occupying forces to the domestic laws of the occupied State. It has been suggested that occupation establishes a quasi trusteeship, i.e. that the occupying power acts as a trustee for the legitimate government of the occupied State and is bound by the treaty obligations of the beneficiary. ${ }^{156}$ It is, however, generally accepted that the occupying power is not the successor, trustee, agent or representative of the government of the occupied State. ${ }^{157}$ The occupying State is generally unrestrained by the treaty obligations of the occupied State; an exception being treaties fixing boundaries or establishing a boundary or other territorial regime. Such treaties would be binding even in cases of the lawful incorporation of the occupied territory. ${ }^{158}$ In this connection it is interesting to note that the British Government, in a Memorandum of 17 May 1944,

154 See Parkerson, supra n. 16, 106, 115-116, 132; Seibt, supra n. 14, 457 n. 106 who quotes from a letter of the German Foreign Office of 15 February 1990 which states: "As long as the occupying power tolerates the presences of diplomatic missions, it is bound by the international obligations of the occupied State." (translation by the author). See also Franz von Liszt and Max Fleischmann, Das Völkerrecht, 12th edn., Berlin 1925, 491 who took the view that the rights (and duties) under treaties between the occupied State and third States were to be exercised by the occupant.

155 E.g. in the United Kingdom the Vienna Convention on Diplomatic Relations has the force of law by virtue of Section 2(1) of the Diplomatic Privileges Act 1964.

156 Seibt, supra n. 14, 448-450.

157 Von Liszt and Fleischmann, supra n. 154, 490; United States Judge Advocate Generals School, supra n. 17, 71; Charles Rousseau, Droit international public, Paris 1953, 568; Oscar M. Uhler, "Besetzung, kriegerische", in: Karl Strupp and Hans-Jürgen Schlochauer (eds.), Wörterbuch des Völkerrechts, 2nd edn, Berlin 1060, vol. I, 195-198 at 195; Gasser, supra n. 147, 245.

158 See Vienna Convention on Succession of States in Respect of Treaties, done at Vienna on 23 August 1978, 1946 UNTS 3, Arts. 11, 12. See also United States Judge Advocate Generals School, supra n. 17, 72 . 
took the view that as "the occupying power" in Italy it was not "bound in any way by the obligations set forth in [Article 12 of] the Lateran Treaty, at any rate insofar as they may conflict with military and security considerations". ${ }^{159}$ Article 12 of the Lateran Treaty deals with the status of foreign diplomats accredited to the Holy See living outside the Vatican in Rome. Subjecting the occupying power to the treaty obligations of the occupied State resulting from the establishment of diplomatic missions in its territory would be contrary to the general principle that a treaty does not create either obligations or rights for a third State without its consent (pacta tertiis nec nocent nec prosunt). ${ }^{160}$ It can hardly be argued that States, by concluding the Vienna Convention, have established an objective regime that applies to all their territories and is creating obliga- tions on all States.

There is also a more general objection to the application of the Vienna Convention on Diplomatic Relations to belligerent occupants. The Vienna Convention was not intended to apply in times of armed conflict. ${ }^{161}$ The Netherlands Government in its observations on the draft articles of the International Law Commission referred to "the principle that provisions of the draft articles shall apply only in time of peace and regulate at most the transition from time of peace to time of war". Treatment of diplomats and diplomatic missions during armed conflict was to be governed "by the relevant law of war". ${ }^{162}$ It is therefore suggested that the better view is that the Vienna Convention on Diplomatic Relations is not directly applicable to the occupying power with respect to diplomatic missions and their members in occupied territory, but that the question, as stated in the preamble of the Convention, continues to be governed by the customary law of war rules. ${ }^{163}$ The Convention may provide useful guidance on the contents of these rules, but it cannot be assumed that the Convention rules apply without modification or limitation necessitated

159 FRUS, 1944, vol. IV, 1313-1318 at 1318 and ibidem, 1324-1325 at 1324 (Memorandum of 11 July 1944).

160 VCLT, Art. 34.

161 Ulrich Seidenberger, Die diplomatischen und konsularischen Immunitäten und Privilegien, Frankfurt am Main 1994, 123.

162 Yearbook of the International Law Commission 1958, vol. II, 126.

163 See the statement of the Dean of the Diplomatic Corps in Kuwait that "the conduct of Iraqi authorities violated norms and custom of diplomatic privilege and immunity." (UN Doc. S/22536, 29 April 1991, 10, para. 41). See also L.H. Woolsey, "Peaceful War in China", American Journal of International Law 32 (1938), 314-320 at 319; Parkerson, supra n. 16, 106. 
by military exigencies and security concerns of the occupant. The following section will examine on the basis of past and present diplomatic practice the extent to which the customary and conventional regime coincide and where they differ.

\section{THE TREATMENT OF DiPLOMATIC MisSIONS AND THEIR MEMBERS IN OCCUPIED TERRITORY}

When the United States occupied Baghdad on 9 April 2003, it found a number of foreign diplomatic missions still operating in the Iraqi capital. While most States had evacuated their diplomats to neighbouring countries prior to the outbreak of hostilities, they maintained that their missions remained open although temporarily staffed only by local employees. Only Vatican and Cuban diplomats remained in Baghdad throughout the hostilities. ${ }^{164}$ Russia withdrew its last diplomats from the Iraqi capital on 6 April 2003, but by the beginning of June, Russian diplomats, as diplomats from other States, had returned to Baghdad "to resume full diplomatic service... not just to ensure our presence in the country but also to provide assistance to Russian firms returning to the Iraqi market". ${ }^{165}$ The Indian Embassy in Baghdad had already resumed operations on 21 April 2003, with a first secretary in the mission taking over as chargé d'affaires. ${ }^{166}$ By 20 May 2003, there were some 20 foreign diplomats back in Baghdad. ${ }^{167}$ The occupation forces were thus faced with the question of how to treat these diplomats and their missions.

164 See the Note of the Cuban Ministry of Foreign Affairs, dated 6 April 2003: "Since March 19, when the war in Iraq began, Ernesto Gómez Abascal, the Cuban ambassador, and a further four Cuban diplomats have been present in the Cuban diplomatic mission in Baghdad... Our comrades have remained there in a dangerous situation for reasons of principle to fulfil their functions and maintain the country informed of the development of events. Their position as diplomats is absolutely neutral and the U.S. government is aware of the exact location of all the diplomatic headquarters, including that of Cuba. As far as is known, the only embassies remaining open in Baghdad are those of the Vatican and Cuba... Our reduced personnel will remain in their headquarters. We trust that their diplomatic status will be respected by all the belligerent parties, even if there is fighting in the area where the embassy is located or in its vicinity." (on file with author).

165 "Russia to send diplomats back to Baghdad", Agence France Presse-English, 3 June 2003, available at http://web.lexis-nexis.com/executive/ (last visited 28 July 2003).

166 "India send Secy on Iraq mission", Indian Express, 22 April 2003, available at http://web.lexis-nexis.com/executive/ (last visited 22 July 2005).

167 "Democracy in Iraq is not a sure thing", Windsor Star (Ontario), 21 May 2003, A8. 


\section{Privileges and Immunities of Diplomatic Agents}

The United States took the position that "there are no diplomatic privileges right now in anywhere in Iraq"168 because "there is no Iraqi government that can grant diplomatic privileges and diplomatic immunities for foreign diplomats inside Iraq". ${ }^{169}$ This view was challenged by Russia. On 3 June 2003, the Russian foreign ministry spokesman declared: "We are expecting the occupying forces in Iraq to ensure, as is stipulated by international legal norms, the diplomatic status and immunity of foreign diplomatic missions working in Baghdad". 170

According to Art. $43 \mathrm{HR}$, the occupant shall leave the laws in force in the occupied territory in place, unless absolutely prevented. The Vienna Convention on Diplomatic Relations will usually be part of the domestic law of the occupied State and will continue to be binding on the institutions of the occupied State. Foreign diplomats will thus continue to enjoy privileges and immunities within the legal order of the occupied State. The crucial question is whether and, if so, to what extent foreign diplomats are immune from the jurisdiction of the occupying power. Three days after the occupation of Addis Ababa on 2 May 1936, the Italian Commander-in-Chief informed the heads of the diplomatic missions in Addis Ababa that the legations would enjoy the recognized privileges for the representation of the interests of the countries they represented and the protection of their subjects. Actions contrary to Italian laws and military ordinances, however, would not be recognized. ${ }^{171}$ No protest was lodged then by the British Government. The situation, however, was different with regard to the Iraqi occupation of Kuwait. During a press conference on 27 September 1990, the British Foreign and Commonwealth Office took the view that "[u]nder the Vienna Convention on Diplomatic Relations our diplomats enjoyed total immunity from Iraqi

168 US Department of State, Daily Press Briefing (Corrected), Richard Boucher, Spokesman, Washington, DC, 29 May 2003, available at $h t t p: / / w w w . s t a t e . g o v / r / p a / p r s / d p b / 2003 / 21062 . h t m$ (last visited 22 June 2005)

169 "US does not view Russian Embassy in Iraq as diplomatic mission", Diplomatic Panorama, 14 July 2003, available at http://web.lexis-nexis.com/executive/ (last visited 22 June 2005).

170 "Russia to return diplomatic workers to Baghdad", News Bulletin, 3 June 2003, available at http://web.lexis-nexis.com/executive/ (last visited 22 June 2005).

171 See the statement of the British Prime Minister, Stanley Baldwin, recounting a Note of 5 May 1936 from Marshal Badoglio, the Italian Commander-in-Chief, addressed to the Diplomatic Missions in Addis Ababa: HC Debates, vol. 312, col. 361: 13 May 1936. 
criminal law". ${ }^{172}$ This statement must be seen against the background of the illegal annexation of Kuwait by Iraq, and the consequent illegal extension of Iraqi criminal law to the occupied territory. It is suggested that neither of these positions adequately reflects customary international law rules on privileges and immunities of foreign diplomats in occupied territory. The US Army Judge Advocate General's School handbook on Law of Belligerent Occupation provides that "if a diplomatic agent of a neutral power is found on occupied territory, he must be regarded as inviolable as long as his actions are harmless". ${ }^{173}$ Similarly, the US War Department Field Manual on The Rules of Land Warfare provides that diplomatic agents of neutral countries in occupied territory must be treated with all courtesy and be permitted such freedom of action as is possible to allow, with due regard to the necessities of war. ${ }^{174}$ It is submitted that while diplomatic agents in occupied territory retain their diplomatic status, they cannot expect to enjoy all their immunities and privileges to the fullest extent. These will in practice be limited by the military necessities and security concerns of the belligerent occupant, who is alone the judge of such necessities. ${ }^{175}$

\section{Inviolability of the Premises of Diplomatic Missions}

The question of the inviolability of the premises of diplomatic missions in occupied territory usually arises when members of the government of the occupied State are suspected of hiding in friendly foreign missions, or when the archives of the defeated government are believed to have been transferred there. The premises of diplomatic missions in occupied territory (as well as the archives and documents of the mission) are inviolable; the occupying authorities may not enter them, except with

172 "United Kingdom Materials on International Law 1990", British Year Book of International Law 61 (1990), 540.

173 United States Judge Advocate General's School, supra n. 17, 79. See also ibid., 80 and Oppenheim, supra n. 98, 808, '400 providing that a neutral diplomat who sides with the occupied State loses his immunity and is liable to arrest by the occupant.

174 War Department Field Manual 27-10: The Rules of Land Warfare, Washington 1940, para. 398.

175 Satow, supra n. 65, 342, '364; von Liszt and Fleischmann, supra n. 154, 491; von Glahn, supra n. 14, 87; the same, supra n. 64, 692. During the US occupation of Grenada US forces searched the Soviet Embassy's official diplomatic consignment and the personal luggage of Soviet diplomats before loading them on US military cargo plane which brought Soviet diplomats to Mexico ("US Troops Search Diplomats Leaving Grenada", Washington Post, 5 November 1983, A21). 
the consent of the head of the mission. ${ }^{176}$ According to the International Court of Justice (ICJ) the principle of the inviolability of the persons of diplomatic agents and the premises of diplomatic missions is one of the very foundations of the long-established rules of diplomatic law. The Court referred to the "fundamental character of the principle of inviolability" and stressed that "[e]ven in the case of armed conflict... the inviolability of the members of a diplomatic mission and of the premises, property and archives of the mission must be respected by the receiving State". ${ }^{177}$ Although the Court referred only to the "receiving State", the same must apply to the occupying power. The British Foreign and Commonwealth Office, with regard to the British Embassy in Kuwait, stated on 27 September 1990: "Embassy buildings were inviolable: Iraqi authorities could not enter them without the Ambassador's explicit agreement". ${ }^{178}$ Practice shows that occupation forces have generally scrupulously observed the inviolability of diplomatic premises. When on 6 July 1936 a party of Italian policemen entered the grounds of the British legation in Addis Ababa with a view to occupying the radio station, the British Government lodged a protest with the Italian Government in Rome, and the policemen were withdrawn. ${ }^{179}$ The raid by US troops on the residence of the Nicaraguan Ambassador in Panama was widely condemned as a violation of international law; ${ }^{180}$ US officials subsequently admitted that the action had violated international law and offered an apology to Nicaragua. ${ }^{181}$

The occupying power is also under a special duty to take all appropriate steps to prevent any disturbances of the peace of the mission or impairment of its dignity. ${ }^{182}$ When General Noriega took refuge in the Papal Nunciature in Panama from 24 December 1989 to 3 January 1990, US troops surrounded the embassy premises, sealed off the neighbourhood, shot out the street lights, searched automobiles that entered and ex-

176 Cfr. VCDR, Art. 22(1), Art. 24.

177 United States Diplomatic and Consular Staff in Tehran (USA v. Iran), Judgment, ICJ Reports 1980,3 at 40 , para. 86 .

178 "United Kingdom Materials on International Law 1990", British Year Book of International Law 61 (1990), 540.

179 HC Debates, vol. 314, col. 2250: 16 July 1936. The legation premises in Addis Ababa continued to "enjoy extra-territorial rights"; see ibidem, vol. 312, col. 1532: 22 May 1936.

180 See supra at nn. 127-133.

181 'President Apologizes For Troops' Blunder; Nicaraguan Envoys House Searched in Panama", Washington Post, 31 December 1989, A1.

182 Cfr. VCDR, Art. 22(2). 
ited the premises, and bombarded the building with loud rock music. ${ }^{183}$ In response to the US actions, Joaquin Navarro-Valls, the chief spokesman of the Holy See, declared on 29 December: "An occupying power cannot interfere with the work of a diplomatic mission". ${ }^{184}$ The Holy See subsequently submitted to the attention of the UN Secretary-General "violations of diplomatic immunity in regard to the Apostolic Nunciature" by US occupation forces in Panama at the end of December 1989 and beginning of January 1990. The Holy See complained of an "invasion of privacy" of the diplomatic mission and its personnel [by the loud playing of rock music] as well as of "encirclement, perquisitions and controls" by US armed forces. ${ }^{185}$

A possible abuse of diplomatic privilege by a diplomatic mission or a failure to comply with the rules relating to diplomatic asylum does not deprive the mission of its inviolability. As the ICJ pointed out:

The rules of diplomatic law, in short, constitute a self-contained régime which, on the one hand, lays down the receiving State's obligations regarding the facilities, privileges and immunities to be accorded to diplomatic missions and, on the other, foresees their possible abuse by members of the mission and specifies the means at the disposal of the receiving State to counter such an abuse. ${ }^{186}$

This finding still holds true even in the age of international terrorism and weapons of mass destruction. In the case of illicit activities by a diplomatic mission, the occupying power may not enter and search the premises of the mission. It may only request the sending State to recall either individual members of the mission or the mission itself. ${ }^{187}$ The occupant may, however, surround the premises of the diplomatic mission so as to prevent the escape of fugitives. The occupying forces may also

183 See Parkerson, supra n. 16, 101.

184 "Vatican sees 'US occupation' of Panama; Troops fire on Nicaraguan Embassy; US invasion of Panama," The Boston Globe, 30 December 1989, 1; "Vatican assails U.S. demands for Noriega", Chicago Tribune, 30 December 1989, 1; "Vatican stops Noriega talks in US protest; Invasion of Panama", The Times, 30 December 1989, 1.

185 "Consideration of Effective Measures to Enhance the Protection, Security and Safety of Diplomatic and Consular Missions and Representatives. Report of the Secretary-General", UN Doc. A/45/455, 11 September 1990, 17.

186 United States Diplomatic and Consular Staff in Tehran (USA v. Iran), Judgment, ICJ Reports 1980,3 at 40 , para. 86 .

187 See ibidem, 38 , para. 83 and $39-40$, para. 85 . 
stop and search non-diplomatic cars leaving the premises. The searching of diplomatic automobiles, on the other hand, is more complex. In principle, a diplomatic mission's vehicles share the inviolability of its premises. ${ }^{188}$ In certain circumstances, such searches may be justified by military necessity and the occupant's security concerns. However, blanket searches of all diplomatic vehicles would not be justified. 189

\section{Duty to Protect the Premises of Diplomatic Missions}

During the US occupation of Iraq, foreign embassies in Baghdad became the target of attacks. Several diplomatic missions were ransacked by looters immediately after the entry of US troops into Baghdad and the collapse of the Iraqi Government. In the following months, several foreign missions were bombed, including the Embassy of Jordan on $7 \mathrm{Au}-$ gust 2003 and the Turkish Embassy on 14 October 2003. Several States took the view that the US occupying forces were responsible for protecting the premises of their diplomatic missions. After the Belgian Embassy had been ransacked, a Belgian Foreign Ministry spokesman declared on 13 April 2003: "The occupying forces are responsible for protecting people and property". ${ }^{190}$ On the looting of the Chinese Embassy, China made "representations" to the United States. The Chinese Foreign Ministry spokesman said: "According to the international law, parties engaged in war have the obligation to secure people and property of foreign embassies and consulates". ${ }^{191}$ On 4 June 2003, the Russian Foreign Ministry spokesman said that Russia "expects the occupying powers in Iraq to ensure, in line with international legal norms, the status and security of foreign diplomatic missions working in Baghdad". ${ }^{192}$

\footnotetext{
188 Cfr. VCDR, Art. 22(3).

189 See Parkerson, supra n. 16, 136.

190 "Belgium, PRC condemn looting of Baghdad embassies, urge US, UK to restore order", World News Connection, 13 April 2003, available at http://web.lexis-nexis.com/executive/ (last visited 22 July 2005).

191 "China condemns looting of Baghdad embassy, demands US action", Agence France Presse-English, 13 April 2003, available at http://web.lexis-nexis.com/executive/ (last visited 22 July 2005).

192 "Russia to send diplomats back to Baghdad", Agence France Presse-English, 3 June 2003, available at http://web.lexis-nexis.com/executive/ (last visited 22 July 2005). See also the statement of the Russian Foreign Ministry spokesman on 12 April 2003: "We believe that the occupying troops, who under international law bear responsibility for maintaining law and order and for handling the humanitarian aspects of the situation in Iraq, should also provide for the security of diplomatic missions." ("Russian Embassy in Baghdad working normally-Foreign Ministry", BBC Moni-
} 
A situation similar to that in Baghdad in April 2003 existed in May 1936 in Addis Ababa. As a result of the disappearance of the Ethiopian Government, rioting and looting broke out in the Ethiopian capital, endangering foreign diplomatic missions. The British Prime Minister, Stanley Baldwin, stated with regard to the protection of the British Legation in Addis Ababa: "primary responsibility for the maintenance of order in Addis Ababa now rests with the Power which is in military occupation of that place". ${ }^{193}$ The Italian occupation troops accordingly provided military protection by placing armed guards outside the compounds of foreign legations which did not possess adequate legation guards. ${ }^{194}$ On 5 May 1936, the US Vice Consul appealed to the Italian occupation forces for special protection of the US Legation in Addis Ababa, which was duly accorded. ${ }^{195}$

It seems that the question is not so much about the protection of foreign diplomatic missions in occupied territory as about the standard of protection. In a Historic Review of CPA Accomplishments, it says that the Facilities Protection Service (FPS) was "protecting over 30 embassies" during the US occupation. ${ }^{196}$ The Russian Embassy in Iraq was protected by several armoured vehicles of the US army until at least mid-July 2003. ${ }^{197}$ However, on 12 June 2003 the Iraqi Foreign Ministry, which was operating under the control of its senior US advisor, Ambassador David Dunford, send a circular to "foreign liaison offices"198 in Baghdad which reads in part:

The ministry wishes to inform foreign liaison offices in Baghdad that the Coalition Provisional Authority (CPA) has announced that members of foreign liaison offices in Iraq enter and remain in Iraq at their own risk.

toring International Reports, 12 April 2003, available at http://web.lexis-nexis.com/executive/ (last visited 22 July 2005).

193 HC Debates, vol. 312, col. 11: 11 May 1936.

194 FRUS, 1936, vol. III, 266. See also ibid., 263-265.

195 See Hyde, supra n. 49, vol. III, 1254 n. 8.

196 Coalition Provisional Authority, An Historic Review of CPA Accomplishments, Baghdad, Iraq, 28 June 2004, 15, available at http://www.cpa-iraq.org/pressreleases/20040628_historic_review_cpa.doc (last visited 22 June 2005).

197 "Intelligence about Saddam behind Russian-US row over Russians' safety in Baghdad", BBC Worldwide Monitoring, 14 July 2003, available at http://web.lexis-nexis.com/executive/ (last visited 22 June 2005).

198 The term "foreign liaison offices" was used because the occupation authorities did not recognize the diplomatic status of foreign diplomatic missions. 
Coalition forces generally undertake to protect the property of foreign governments in Iraq consistent with the overall need to maintain security in Iraq. The CPA cannot, however, guarantee the security of a foreign liaison mission or its personnel. ${ }^{199}$

The message that the occupying authorities would not assume responsibility for the security of foreign diplomatic missions was also echoed by the CPA Administrator, Ambassador Paul Bremer, who stated in Memorandum No. 5 of 22 August 2003: "Recognizing, that while the Coalition Provisional Authority generally seeks to protect diplomatic premises insofar as the current security environment permits, it is not required to protect diplomatic facilities beyond the general obligation to restore, and ensure as far as possible, public order and safety". ${ }^{200}$

Because of the precarious security situation in Iraq, the CPA allowed foreign diplomatic missions to deploy their own security forces to protect mission premises. However, this had to be fully coordinated with and agreed by the occupation forces, and the foreign missions had to comply with the occupation forces' procedures on weapons control.

The question is what standard of protection the occupying power must provide to foreign diplomatic missions. Ambassador Bremer alluded in his Memorandum to Art. 43 HR which provides that the occupant "shall take all the measures in his power to restore, and ensure, as far as possible, public order and safety". This implies that the occupant is responsible only for the general security situation in the occupied territory and does not have a special obligation to protect foreign missions. Article 22(2) VCDR, on the other hand, imposes a "special duty" on the receiving State "to take all appropriate steps to protect the premises of the mission against any intrusion or damage and to prevent any disturbance of the peace of the mission or impairment of its dignity." While in the first case, regular military patrols in the area of the missions might

199 "US-led coalition warns foreign diplomats they remain in Iraq at own risk", Agence France Presse-English, 12 June 2003). See also the statement by the US Ambassador to Russia on 12 July 2003: "We are not obstructing the Russian personnel that is still working in the former Russian Embassy in Baghdad but we do not consider it a diplomatic mission at this time. We do not assume responsibility for their safety although efforts to step up security will ultimately benefit them." (US does not view Russian Embassy in Iraq as diplomatic mission", Diplomatic Panorama, 14 July 2003, both available at http://web.lexis-nexis.com/executive/ (last visited 22 June 2005)).

200 Coalition Provisional Authority Memorandum No. 5 on the Implementation of Weapons Control Order No. 3 (CPA/ORD/23 May 2003/03), CPA/MEM/22 Aug 2003/05, preambular para. 2. 
suffice, "a special duty to take all appropriate steps" could, depending on the security situation, require that the occupying power permanently stations a sufficient number of troops, tanks and armed vehicles in the vicinity of the missions and installs barbed wire, check-points and takes other defensive measures to protect the premises of foreign missions. State practice as to the standard of protection is inconclusive. It is submitted that sending States are probably expecting the occupant, like the receiving State, to take all appropriate steps to protect the premises of their diplomatic missions, but that these steps must necessarily be subject to the military exigencies of the occupying forces.

\section{Restrictions on the Operations of Diplomatic Missions}

The actions of foreign diplomats must not prejudice the military interests of the occupant. The question is to what extent military necessities and security concerns allow the operations of diplomatic missions in occupied territory to be restricted. It is suggested that, contrary to the provisions of the VCDR, the occupying power may limit diplomatic missions' contacts with the government or local authorities of the occupied State. For example, after the occupation of Addis Ababa, the Italian Commander-in-Chief informed the heads of the diplomatic missions that contacts with any other quarter than his chief of cabinet would not be recognized. ${ }^{201}$ Similarly, the Supreme Commander for the Allied Powers in Japan informed the diplomatic missions of neutral countries in Japan that contacts with the Japanese Government were to be through the Supreme Commander Allied Powers. ${ }^{202}$

In cases where absolute military security so requires, and only in such cases, the occupant may also (temporarily) limit communications between the diplomatic missions and their sending State. ${ }^{203}$ Article 5(2) GC IV recognizes the concerns of the occupying power for its security. It allows the occupation forces, in those cases where absolute military security so requires, to restrict the rights of communication of persons under definite suspicion of activity hostile to the security of the occupying

201 See HC Debates, vol. 312, col. 361: 13 May 1936.

202 Directive by the Supreme Commander, Allied Powers, Japan (MacArthur) to the Japanese Government, 4 November 1945: FRUS, 1945, vol. VI, p. 852. See also Yamaguchi, supra n. $42,106$.

203 See also the restrictions imposed on diplomatic communications by the United Kingdom during the two World Wars; see Eileen Denza, Diplomatic Law, 2nd edn., Oxford 1998, 174. 
power. Upon the break in relations between the United States and Germany on 3 February 1917, the German occupation authorities in Belgium stopped the courier service of the US Minister at Brussels; a privilege he had enjoyed until then. ${ }^{204}$ In July 1936, the Italian occupation authorities in Addis Ababa ordered foreign diplomatic missions to discontinue the use of their wireless installations for purposes of transmission. The missions complied under protest. ${ }^{205}$ The Instrument of Surrender of Italy, signed at Malta on 29 September 1943, provided in section 25(B): "The United Nations reserve the right... to prescribe and lay down regulations... regarding communications emanating from or destined for the representatives of neutral countries in Italian-territory". ${ }^{206}$ During the occupation of Grenada, US forces cut the Soviet Embassy's communications with Moscow. 207

The occupant is not entitled to cordon off the premises of diplomatic missions and to prevent diplomatic agents from leaving the mission, or citizens of the sending State from visiting the mission. ${ }^{208}$ There is, however, no general right of access to the mission for citizens of the occupied State. The occupant may establish checkpoints and control people and cars in the vicinity of diplomatic premises. It is also permissible to stop persons outside the mission and request that they provide proof of their diplomatic status.

Occupation authorities have also prescribed conditions for the continued operation of diplomatic missions. These can include that only nationals of the sending State or of the occupying power may be employed by the diplomatic mission, i.e. that the mission may not employ nationals of the occupied State; no observations or reports of a military character can be made; no journeys to be undertaken in the occupied territory without prior notification of the military authorities; and entry into certain areas of the occupied territory to be prohibited. ${ }^{209}$

204 FRUS, 1917, Supplement 1 (1931), 656.

205 See HC Debates, vol. 314, col. 2250: 16 July 1936.

206 Nouveau Recueil Général de Traités, 3rd series, vol. 41, 876 at 880.

207 Time Magazine [US Edition], 14 November 1983, 18.

208 See S/RES/667 (1990) of 16 September 1990, para. 4 ("Iraq... take no action to hinder the diplomatic and consular missions in the performance of their functions, including access to their nationals and protection of their person and interests").

$209 C f r$. the restrictions imposed upon the US consul in Belgrade during the occupation of Serbia by Austro-Hungarian troops: FRUS, 1915, Supplement, 922-923. 


\section{THE ESTABLISHMENT OF FOREIGN LIAISON MISSIONS IN OCCUPIED TERRITORY}

After the occupation of Iraq, several countries that did not have diplomatic relations with Iraq under Saddam Hussein sent diplomats to contribute to coalition efforts to rebuild the country's institutions and infrastructure and to establish contacts with the new interim institutions of Iraqi self-government. The Iraqi Foreign Ministry resumed work on 11 May 2003 under new management put in place by the US-led coalition and under the supervision of David Dunford, the ministry's senior US advisor. ${ }^{210}$ The first country to re-establish a diplomatic presence in Iraq was the United Kingdom. ${ }^{211}$ On 5 May 2003, a team of British diplomats headed by Christopher Segar returned to their former embassy in Baghdad to establish a "British Office" there. Other countries followed suit. Australia announced on 13 May 2003 the establishment of an "Australian Representative Office" in the Iraqi capital. ${ }^{212}$ The CPA Memorandum No. 5 of 22 August 2003 lists 35 States maintaining "foreign liaison missions" in Baghdad, several of which previously had diplomatic missions (such as China, Egypt, Morocco, Palestine, Russia, Tunisia, and Turkey). ${ }^{213}$ It seems that the occupation authorities tried to resolve the dispute about the legal status of existing diplomatic missions in Iraq by treating them as foreign liaison missions. Although the foreign liaison missions were diplomatic missions in all but name, ${ }^{214}$ there is an impor-

210 "Iraqi foreign ministry getting back to work", Agence France Presse-English, 11 May 2003, available at http://web.lexis-nexis.com/executive/ (last visited 22 June 2005).

211 The United Kingdom had broken off diplomatic relations with Iraq and had closed its embassy in Baghdad on 12 January 1991.

212 "Australia to reopen Baghdad Mission >when security conditions permit", BBC Monitoring International Reports, 14 May 2003, available at http://web.lexis-nexis.com/executive/ (last visited 27 July 2005).

213 Algeria, Australia, Bahrain, Bangladesh, Bulgaria, China, Czech Republic, Denmark, Egypt, France, Germany, Greece, India, Italy, Iran, Japan, Jordan, [South] Korea, Morocco, Netherlands, Palestine, Philippines, Poland, Romania, Russia, Serbia/Montenegro, Sri Lanka, Spain, Sudan, Switzerland, Tunisia, Turkey, UAE, United Kingdom, United States ("Coalition Provisional Authority Memorandum No. 5 on the Implementation of Weapons Control Order No. 3 (CPA/ORD/23 May 2003/03)", CPA/MEM/22 Aug 2003/05, 4, Annex A).

214 This is shown by the fact that after 30 June 2004 all references to "foreign liaison mission" were to apply equally to diplomatic and consular missions; see section 2(12) of the Coalition Provisional Authority Order No. 100 on the Transition of Laws, Regulations, Orders, and Directives Issued by the Coalition Provisional Authority, CPA/ORD/28 JUNE 2004/100. See also section 6(5)(a) which provides that, in CPA Memorandum Number 5, Implementation of Weapons Control Order 
tant difference in legal status between newly established foreign liaison missions and diplomatic missions existing prior to the occupation. As pointed out by the US State Department spokesman, the occupying power has "the right to allow people to enter [Iraq] and to be there, but that doesn't give us the right to grant diplomatic status to people in the country". ${ }^{215}$ The CPA could not take accreditations for diplomatic agents. ${ }^{216}$ It was for this reason that the British Government established a "British Office" and did not formally reopen its embassy in the Iraqi capital. A statement issued by the British Office on 5 April 2003 said: "We are not using the terms 'embassy' and 'ambassador' since there is no Iraqi Government yet for an ambassador to present credentials to. But otherwise, Mr Christopher Segar and his staff will fulfil the normal functions of an embassy and ambassador". ${ }^{217}$ Any status, privileges or immunities granted by the occupation authorities to foreign liaison missions and their members will, as a rule, not be binding on the (returning) legitimate government of the occupied State. If these diplomats remain in the territory after the end of the occupation, their sending State must obtain the agrément of the legitimate government of the receiving State. ${ }^{218}$ Thus, on 29 June 2004, one day after the hand-over of power to the Iraqi interim government, the first three western ambassadors from the United States, Australia and Denmark presented their credentials to Iraq's interim President Ghazi al-Yawar. The new British Ambassador presented his credentials on 7 July.

Number 3 with Annex, all references to "foreign liaison mission[s]" shall be replaced with "diplomatic or consular missions".

215 UN Department of State, Daily Press Briefing (Corrected), Richard Boucher, Spokesman, Washington, DC, 29 May 2003, available at $h t t p: / / w w w . s t a t e . g o v / r / p a / p r s / d p b / 2003 / 21062 . h t m$ (last visited 22 June 2005)

216 "US-led administration says no plans to accredit foreign diplomats", Agence France Presse-English, 31 May 2003, available at http://web.lexis-nexis.com/executive/ (last visited 22 June 2005).

217 "Britain opens de facto embassy in Iraq", Agence France Presse-English, 5 May 2003,

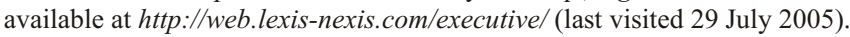

218 Immunity from legal process was initially limited to conduct during the period of authority of the CPA; see Coalition Provisional Authority Order Number 17 on the "Status of the Coalition, Foreign Liaison Missions, Their Personnel and Contractors", CPA/ORD/26 June 2003/17, sec. 4. The legitimate government may, however, be bound by laws put in place by the occupying authority providing for privileges and immunities for these missions and their members in the time after the occupation; see Coalition Provisional Authority Order Number 17 (Revised) on the "Status of the Coalition Provisional Authority, MNF-Iraq, Certain Missions and Personnel in Iraq", CPA/ORD/27 June 2004/17. 
The occupying power may temporarily grant privileges and immunities to foreign diplomats until a new government is in place. These will largely be identical with those enjoyed by diplomatic missions in occupied territory under customary international law. On 27 June 2003, the CPA promulgated Order No. 17 which provided that foreign liaison missions, their personnel, their property, funds and assets were to be immune from Iraqi legal process, i. e. from any arrest, detention or legal proceedings in the Iraqi courts or other Iraqi bodies, whether criminal, civil, administrative or other in nature. ${ }^{219}$ Foreign liaison mission personnel was defined as "those individuals who have been issued Foreign Liaison Mission personnel identification cards by the Iraqi Ministry of Foreign Affairs under the supervision of the CPA". ${ }^{220}$ The immunity granted was absolute, personal immunity and not just immunity for official acts. Immunity was, however, limited to immunity from the "Iraqi legal process". A Public Notice of 26 June 2003 made it clear that "Foreign Liaison Missions and their personnel enjoy immunity from Iraqi legal proceedings, but are subject to the CPA's jurisdiction". ${ }^{221}$ Foreign Liaison Mission personnel was to respect the applicable Iraqi laws and the Regulations, Orders, memoranda and Public Notices issued by the Administrator of the Coalition Provisional Authority. ${ }^{222}$ Claims for property loss or damage and for personal injury, illness or death, or in respect of any other matter arising from or attributed to Foreign Liaison Mission personnel are to be submitted and dealt with by the sending State of the Mission in a manner consistent with its national laws. ${ }^{223}$ Foreign Liaison Missions were also exempted from the 5 per cent reconstruction levy imposed on all goods imported into Iraq. 224

The general security situation in Iraq made it necessary to grant more extensive security privileges to foreign liaison missions than those normally enjoyed by diplomatic missions under the VCDR. Thus, Foreign

219 Order No 17 on the "Status of the Coalition, Foreign Liaison Missions, Their Personnel and Contractors", CPA/ORD/26 June 2003/17, sec. 2(1) and (3) and sec. 1(3). On the orders of the CPA, see Sean D. Murphy, "Contemporary Practice of the United States Relating to International Law: Use of Force and Arm Control: Coalition Laws and Transition Arrangements During Occupation of Iraq", American Journal of International Law 98 (2004), 601-606 at 602.

220 CPA/ORD/26 June 2003/17, sec. 1(2).

221 Office of the Administrator of the Coalition Provisional Authority Baghdad, Iraq: Public Notice Regarding the Status of Coalition, Foreign Liaison and Contractor Personnel, 26 June 2003.

222 CPA/ORD/26 June 2003/17, sec. 2(2).

223 Ibidem, sec. 6(2).

224 See CPA/ORD/19 September 2003/38, sec. 1(4), 2(1)(f), 2(2)(f). 
Liaison Missions were allowed to bring into Iraq and/or maintain their own security forces providing security services to the missions. The CPA authorized Foreign Liaison Missions to enter into and execute contracts for security services, and expressly permitted the providers of such services to perform those actions that are necessary to ensure proper security of foreign mission personnel and facilities, including the carrying of weapons. ${ }^{225}$

\section{CONCLUSIONS}

The United States did not try to justify its raid on the Palestinian Embassy in Baghdad and detention of the Palestinian diplomats by citing Palestine's lack of statehood, or by claiming that it did not recognize a State of Palestine and so, for that reason alone, the Palestinian Embassy and its personnel did not enjoy diplomatic status. It is submitted that such an argument was wisely avoided, as the question of diplomatic status of a foreign mission in occupied territory does not depend on the view of the occupying power as to the status of the sending State, but on that of the occupied receiving State. Honouring the diplomatic status of a foreign mission in occupied territory cannot establish diplomatic relations between the occupying and the sending State, nor does it imply recognition of the sending State by the occupying power. The United States instead chose to justify its actions by claiming that all diplomatic missions in Iraq had lost their diplomatic status with the lapse of the Iraqi Government. It has been shown that this view is not in conformity with either diplomatic practice or precedent. Foreign diplomatic missions in Iraq and their personnel continued to enjoy diplomatic status throughout the occupation. The United States would have been perfectly entitled to request States (temporarily) to recall their missions from Iraq; as long as it chose not to do so, it was bound by the rules of customary international law to respect the diplomatic status of foreign diplomats and missions. On 30 November 1990, US President George Bush said with regard to

225 Coalition Provisional Authority Memorandum No. 5 on the Implementation of Weapons Control Order No. 3 (CPA/ORD/23 May 2003/03), CPA/MEM/22 Aug 2003/05. 
the treatment of the US Embassy by Iraqi occupation forces in Kuwait: "This treatment of our embassy violates every civilized principle of diplomacy". ${ }^{226}$ Some 13 years later, the same may be said about the US treatment of the Palestinian Embassy in Baghdad and its personnel. 